\title{
Simulated Effects of Sulfur Deposition on Nutrient Cycling in Class I Wilderness Areas
}

\author{
Katherine J. Elliott, * James M. Vose, and Jennifer D. Knoepp USDA Forest Service \\ Dale W. Johnson University of Nevada \\ Wayne T. Swank and William Jackson USDA Forest Service
}

We predicted the effects of sulfate $\left(\mathrm{SO}_{4}\right)$ deposition on wilderness areas designated as Class I air quality areas in western North Carolina using a nutrient cycling model $(\mathrm{NuCM})$. We used three $S$ deposition simulations: current, $50 \%$ decrease, and $100 \%$ increase. We measured vegetation, forest floor, and root biomass and collected soil, soil solution, and stream water samples for chemical analyses. We used the closest climate stations and atmospheric deposition stations to parameterize $\mathrm{NuCM}$. The areas were: Joyce Kilmer (JK), Shining Rock (SR), and Linville Gorge (LG). They differ in soil acidity and nutrients, and soil solution and stream chemistry. Shining Rock and LG have lower soil solution base cation and higher acidic ion concentrations than JK. For SR and LG, the soil solution $\mathrm{Ca} / \mathrm{Al}$ molar ratios are currently 0.3 in the rooting zone (A horizon), indicating $\mathrm{Al}$ toxicity. At $\mathrm{SR}$, the simulated $\mathrm{Ca} / \mathrm{Al}$ ratio increased to slightly above 1.5 after the $30-\mathrm{yr}$ simulation regardless of $S$ deposition reduction. At $\mathrm{LG}, \mathrm{Ca} / \mathrm{Al}$ ratios ranged from 1.6 to 2.4 toward the end of the simulation period, the $100 \%$ increase scenario had the lower value. Low $\mathrm{Ca} / \mathrm{Al}$ ratios suggest that forests at $S R$ and LG are significantly stressed under current conditions. Our results also suggest that $\mathrm{SO}_{4}$ retention is low, perhaps contributing to their high degree of acidification. Their soils are acidic, low in weatherable minerals, and even with large reductions in $\mathrm{SO}_{4}$ and associated acid deposition, it may take decades before these systems recover from depletion of exchangeable $\mathrm{Ca}, \mathrm{Mg}$, and $\mathrm{K}$.
Copyright $\odot 2008$ by the American Society of Agronomy, Crop Science Society of America, and Soil Science Society of America. All rights reserved. No part of this periodical may be reproduced or transmitted in any form or by any means, electronic or mechanical, including photocopying, recording, or any information storage and retrieval system, without permission in writing from the publisher.

Published in J. Environ. Qual. 37:1419-1431 (2008). doi: $10.2134 /$ jeq2007.0358

Received 6 July 2007.

*Corresponding author (kelliott@fs.fed.us).

(c) ASA, CSSA, SSSA

677 S. Segoe Rd., Madison, WI 53711 USA
$A_{\text {and industrialization, wilderness and other natural areas }}^{\text {s a consequence of human land use, poplation growth, }}$ can be threatened by air pollution, climate change, and exotic diseases or pests. Air pollution in the form of acidic deposition is comprised of sulfuric and nitric acids and ammonium derived from emissions of sulfur dioxide, nitrogen oxides, and ammonia. These compounds are largely emitted to the atmosphere by fossil fuel burning and agricultural activities. Once acid compounds enter sensitive ecosystems, they can acidify soil and surface waters, causing a series of ecological changes (Driscoll et al., 2003; Watmough et al., 2005). Acidic deposition has contributed to declining availability of $\mathrm{Ca}, \mathrm{Mg}$, and $\mathrm{K}$ in the soils of acid-sensitive forest ecosystems by leaching $\mathrm{Ca}, \mathrm{Mg}$, and $\mathrm{K}$ from foliage and from soil in the primary rooting zone. Acid deposition can also mobilize aluminum in soils affecting soil solution and drainage waters (National Acid Precipitation Assessment Program, 1998).

Forest ecosystems that are potentially sensitive to the adverse impacts of acidic deposition are found throughout the southern Appalachian region, particularly at high elevation and within Class I areas. Class I areas are federally mandated wilderness areas, national parks, or national wildlife refuges according to the Clean Air Act as amended in 1977. Within wilderness areas, old-growth forests may be more sensitive to atmospheric pollution than young forests, because old trees near the end of their life-cycle are typically more susceptible to environmental stressors, either in the form of air pollution or changes in climate (Pregitzer and Euskirchen, 2004). Similarly, differences in nutrient pool sizes and cycling rates between old and young forests (Knoepp and Swank 1994) implies that responses observed in young or aggrading forests may not be applicable to oldgrowth forests. Sulfur processing within sensitive forest ecosystems is important to understand the acidification of surface waters. Sulfur is the most abundant mobile anion in atmospheric deposition and alters the mobility of other elements, especially acidic ( $\mathrm{H}$ and $\mathrm{Al}$ ) and basic ( $\mathrm{Ca}, \mathrm{Mg}, \mathrm{Na}$, and $\mathrm{K}$ ) cations in soil solutions (Johnson et al., 1982, 1985, 1998; Reuss and Johnson, 1986; Nihlgard et al., 1994; Watmough et al., 2005; Sullivan et al., 2006).

Acidic deposition accelerates $\mathrm{Ca}, \mathrm{Mg}$, and $\mathrm{K}$ losses. Increased acidity solubilizes $\mathrm{Al}$, which displaces $\mathrm{Ca}, \mathrm{Mg}$, and $\mathrm{K}$ from soil

KJ. Elliott, J.M. Vose, J.D. Knoepp, and W.T. Swank, Coweeta Hydrologic Lab., Southern Research Stn., USDA Forest Service, Otto, NC 28763; D.W. Johnson, Dep. of Environmental and Resource Sciences, Univ. of Nevada, Reno, NV 89512; W. Jackson, Air Resources Program, Region 8, USDA Forest Service, Asheville, NC 28804.

Abbreviations: NuCM, nutrient cycling model; JK, Joyce Kilmer/Slickrock wilderness; SR, Shining Rock wilderness; LG, Linville Gorge wilderness. 
exchange sites, which then leach in association with $\mathrm{SO}_{4}$ (Reuss and Johnson, 1986; Huntington et al., 2000). At current rates of $\mathrm{SO}_{4}$ deposition, watershed model simulations indicate that $\mathrm{SO}_{4}$ deposition contributes to chronic soil Ca leaching losses (Huntington et al., 2000; Sullivan et al., 2006). In some eastern deciduous forests, the hydrologic budgets of $\mathrm{SO}_{4}$ indicated that precipitation inputs exceeded streamflow export, suggesting soil $\mathrm{SO}_{4}$ adsorption (Johnson et al., 1980; Swank et al., 1985; Mitchell and Lindberg, 1992). Other studies in the eastern United States have found that decreases in $\mathrm{SO}_{4}$ concentrations in streamwater over the past two decades were linked to decreased $\mathrm{S}$ deposition (Driscoll et al., 1989; Lawrence et al., 1999, 2000; Johnson et al., 2000). At Coweeta in the southeastern United States, there has been a decrease in $\mathrm{SO}_{4}$ dry deposition (Swank and Waide, 1988). However, the rate of decline in stream $\mathrm{SO}_{4}$ is related to the soil $\mathrm{SO}_{4}$ adsorption and desorption capacity, which may result in considerable delays in some systems (Reuss and Johnson, 1986). The mobility of anions such as $\mathrm{SO}_{4}$ and nitrate in acid soils has a direct influence on soil solution and surface water acidity. In acidic soils the counter ions balancing these anions will consist of greater concentrations of $\mathrm{H}^{+}$and $\mathrm{Al}^{3+}$ being removed from cation exchange sites than would be the case in more neutral soils (Reuss and Johnson, 1986). Although $\mathrm{SO}_{4}$ concentrations in deposition have steadily declined, $\mathrm{SO}_{4}$ remains the primary anion associated with acidification of streamwater. Soils with high $\mathrm{SO}_{4}$ adsorption capacities such as those found in the southeast United States may buffer decreases in $\mathrm{S}$ deposition and maintain high $\mathrm{SO}_{4}$ concentrations for decades by desorption of formerly adsorbed $\mathrm{SO}_{4}$, thereby resisting improvements to surface water acidification.

Wet deposition (precipitation) and dry deposition of $\mathrm{SO}_{4}$, aerosol $\mathrm{SO}_{4}$, and the interception of cloud water or fog droplets containing $\mathrm{SO}_{4}$ all contribute to the atmospheric deposition of S (Lindberg, 1992). With passage of the 1970 and 1990 Clean Air Act Amendments, S emissions had decreased by $27 \%$ in 2000 , and are projected to decrease another $7 \%$ by 2010 (Baier and Cohn, 1993). However, in areas near heavily industrialized centers, total $\mathrm{S}$ deposition may remain high because of the combination of higher $\mathrm{SO}_{4}$ concentration in rainfall and high rainfall amounts (National Atmospheric Deposition Program, 1998).

One of the responsibilities of land managers is to protect sensitive wilderness and natural resources by evaluating external stressors such as air pollution, and in some cases making recommendations to the appropriate federal, state, or local air regulatory agency. Predicting future response to altered atmospheric environment conditions requires a modeling approach because of the complexities of nutrient cycling processes in forest ecosystems. A major limitation of modeling, especially in wilderness or other natural areas, is having adequate data to parameterize or calibrate models to assure the necessary level of precision and accuracy for valid model output. One option is to focus on the most sensitive or unique locations within wilderness areas, combining intensive field measurements and a modeling approach. In this article, we used such an approach by utilizing the Nutrient Cycling Model $(\mathrm{NuCM})$ to simulate the effects of three $\mathrm{S}$ deposition levels (current, 50\% decrease, and $100 \%$ increase) on three wilderness areas in western North Carolina. As part of the Integrated Forest Study (IFS), NuCM was developed to synthesize current understanding of nutrient cycling in forests and to predict how forests respond to changing $S$ and $N$ atmospheric deposition rates (Johnson and Lindberg, 1991; Liu et al., 1991a, 1991b). The NuCM model links soil-solution chemical components with traditional conceptual models of forest nutrient cycling on a stand level (Liu et al., 1991a).

Three wilderness areas, designated as Class I air quality in western North Carolina, were chosen for this study because of their potential sensitivity to acidic atmospheric deposition. The area modeled within Joyce Kilmer/Slickrock wilderness contains one of the largest old-growth forests in the eastern United States. The area in SR wilderness is a high elevation, highly disturbed former red spruce forest with high deposition inputs, and frigid soils, with low biological activity. Linville Gorge wilderness was chosen because it is a high elevation acidic cove/ slope forest with little evidence of human disturbance, contains a large area of old-growth forest, and is located on geologic parent material known to be low in $\mathrm{Ca}, \mathrm{Mg}$, and $\mathrm{K}$ (Newell and Peet, 1995) and thus sensitive to acidic deposition.

\section{Materials and Methods}

\section{Site Descriptions}

Joyce Kilmer-Slickrock wilderness, SR wilderness, and LG wilderness are located in the southern portion of the Southern Appalachian Mountains (Fig. 1); and represent three of the five Class I wilderness areas in western North Carolina. Joyce Kilmer/ Slickrock and LG contain two of the few remaining large areas of old-growth forest in the eastern United States (Lorimer, 1980, Runkle, 1981, Runkle, 1982). Detailed descriptions of location, vegetation, soils, and geology for the wilderness areas are provided in Table 1. Joyce Kilmer/Slickrock, SR, and LG are part of the oak-chestnut forest region originally described by Braun (1950). Within this broad forest region, Braun (1950) further subdivided moderate elevation forests into three communities; mixed, mesophytic or cove hardwoods, oak-chestnut (now mixed-oak hardwoods), and oak-pine; and high elevation forests into two communities, northern hardwoods and grassy or heath balds.

Joyce Kilmer/Slickrock is a mixed, deciduous old-growth forest. Shining Rock is a former red spruce forest; it was harvested and then severely burned by wildfires twice (1925 and 1942) (Vanderzanden et al., 1999). Following the fires, there was extensive soil erosion, which had additional negative impacts on base cation availability. Linville Gorge is an oak-pine old-growth forest. All three wilderness areas are within the Blue Ridge Geologic Province and soils are derived from high-grade metamorphosed sedimentary rocks, which are covered by unconsolidated Quaternary-aged colluvial and alluvial deposits (Lesure et al., 1977). The mica gneiss and lower quartzite parent materials at SR and LG result in the formation of soils with low $\mathrm{Ca}, \mathrm{Mg}$, and $\mathrm{K}$ and potentially sensitive to acid deposition. More detailed descriptions of the vegetation, geology, and soils in these wilderness areas can be found in Newell et al. (1997) (JK wilderness), Newell and Peet (1996) (SR wilderness), and Newell and Peet (1995) (LG wilderness).

In JK, three study plots ( 20 by $20 \mathrm{~m}$ ) were placed; one in mesic, cove hardwoods (low-slope), one in mixed-oak hard- 
woods (mid-slope), and one in northern hardwoods (higher elevation, ridge), to represent the three major community types present in the wilderness. For SR and LG, study areas were located in small catchments within the wilderness boundaries. The catchment size within SR was 62 ha and the catchment size within LG was 24 ha. In SR, five 20 by $20 \mathrm{~m}$ plots were located along a 400-m transect at about 70-m intervals parallel to Greasy Cove Prong Creek. In LG, five 20 by $20 \mathrm{~m}$ plots were located along a 400-m transect from near stream to upslope from a first-order stream that drained into the Linville River.

\section{Model Parameterization and Data Collection}

Most of the model input data were derived from measurements taken within each of the three wilderness areas (JK, SR, or LG). Climate data were obtained from NCDC/NOAA climate stations closest to the corresponding wilderness. Where data were unavailable, we used long-term climate data records from the Coweeta Hydrologic Laboratory located in the Nantahala Mountains of

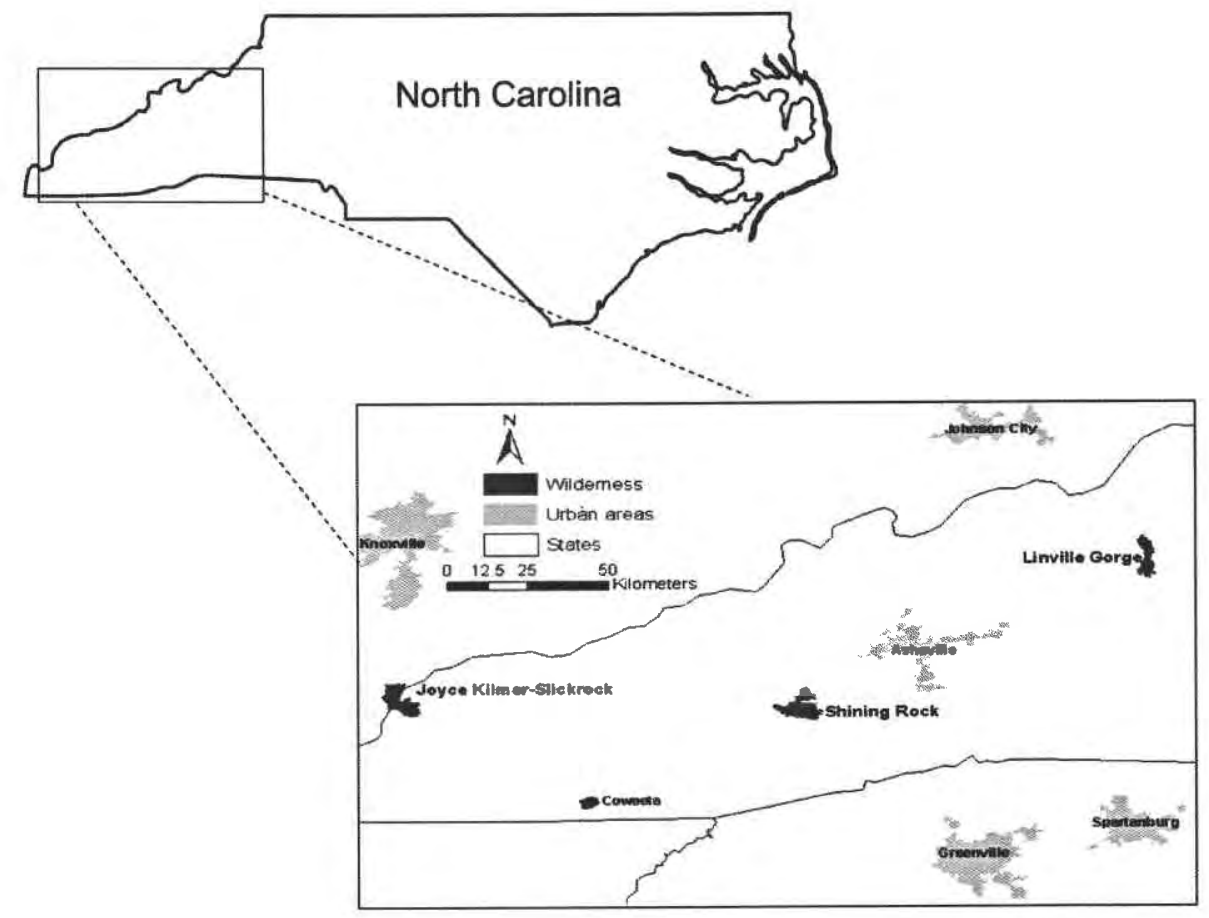

Fig. 1. Locations of three Class I wilderness areas in western North Carolina, USA: Joyce Kilmer/Slickrock wilderness (JK); Shining Rock wilderness (SR); Linville Gorge wilderness (LG); and Coweeta Hydrologic Laboratory Experimental Forest.

western North Carolina (Swank and Crossley, 1988). For a complete description of data requirements for model parameterization see Munsen et al. (1992). In brief, the $\mathrm{NuCM}$ model requires five input data files to parameterize the model for a simulation. These

Table 1. Site descriptions of the three Class I wilderness areas (Joyce Kilmer/Slickrock, Shining Rock, and Linville Gorge) in western North Carolina, United States.

\begin{tabular}{|c|c|c|c|}
\hline Wilderness area & Joyce Kilmer & Shining Rock & Linville Gorge \\
\hline Location (county in NC) & Graham & Haywood & Burke \\
\hline Mountain Range & Unicoi Mountains & Great Balsam Mountains & Grandfather Moutains \\
\hline Size & 6805 ha & 7400 ha & 4390 ha \\
\hline Latitude & $35.22-35.38$ & $35.17-35.28$ & $35.50-35.58$ \\
\hline Longitude & $83.55-84.02$ & $82.59-82.47$ & $81.56-81.52$ \\
\hline Elevation & $250-450 \mathrm{~m}$ & $1450-1550 \mathrm{~m}$ & $1090-1160 \mathrm{~m}$ \\
\hline Geology & Arkosic metasandstone & Mica gneiss & Lower quartzite \\
\hline Soils & $\begin{array}{l}\text { Typic Haplumbrepts; Cheoa series and Umbric } \\
\text { Dystrochrepts; Jeffrey series }\end{array}$ & Typic Haplumbrepts; Wayah series & $\begin{array}{l}\text { Typic Dystrochrepts; Soco- } \\
\text { Ditney series complex }\end{array}$ \\
\hline \multicolumn{4}{|l|}{ Climate } \\
\hline Max temperatures & $25-30^{\circ} \mathrm{C}$ & $27-30^{\circ} \mathrm{C}$ & $21-27^{\circ} \mathrm{C}$ \\
\hline Min temperatures & $12-17^{\circ} \mathrm{C}$ & $11-18^{\circ} \mathrm{C}$ & $14-17^{\circ} \mathrm{C}$ \\
\hline Annual precipitation & $1400 \mathrm{~mm}$ & $1025-1825 \mathrm{~mm}$ & $1250-1625 \mathrm{~mm}$ \\
\hline Vegetationt & $\begin{array}{l}\text { Low elevation, cove-hardwoods; tulip poplarł, } \\
\text { eastern hemlock, and montane oak (northern } \\
\text { red oak, chestnut oak) }\end{array}$ & $\begin{array}{l}\text { High elevation, mixed-hardwood } \\
\text { Subtype of northern hardwood } \\
\text { forest; yellow birch, red maple }\end{array}$ & $\begin{array}{l}\text { Acidic cove and slope; } \\
\text { chestnut oak, red maple }\end{array}$ \\
\hline Mean DBH of overstory (range) & $22.1 \mathrm{~cm}(5.0-150.5)$ & $12.8 \mathrm{~cm}(5.0-44.1)$ & $18.0 \mathrm{~cm}(5.0-71.1)$ \\
\hline Aboveground mass $\left(\mathrm{Mg} \mathrm{ha}^{-1}\right)$ & 400 & 119 & 167 \\
\hline Forest floor mass $\left(\mathrm{g} \mathrm{m}^{-2}\right)$ & 2600 & 1900 & 10,000 \\
\hline Root mass $\left(\mathrm{g} \mathrm{m}^{-2}\right)$ & 1380 & 1000 & - \\
\hline
\end{tabular}


data input files include physiographic, chemistry, meteorologic, deposition, and soil temperature. The meteorologic, deposition, and soil temperature data were created outside the model and input as ASCII files; whereas, the physiographic and chemistry files were created through input menus within the model. The meteorologic data file contains daily values for precipitation, minimum and maximum temperature, cloud cover, dewpoint, atmospheric pressure, and wind speed. For JK, we used climate data from $\mathrm{Na}$ tional Oceanic and Atmospheric Administration (1999) National Climatic Data Center for cooperative climate station (no. 318492) located in Tapoco, NC, and Coweeta Hydrologic Laboratory, Climate Station 28 (CS28), located in Otto, NC. Tapoco is located approximately $24 \mathrm{~km}$ from $\mathrm{JK}$ at $35.45^{\circ} \mathrm{N}$ lat, $83.94^{\circ} \mathrm{W}$ long, and $338 \mathrm{~m}$ elevation. Coweeta, CS28, is located at $35.02^{\circ} \mathrm{N}$ lat, $83.28^{\circ}$ $\mathrm{W}$ long, and $1200 \mathrm{~m}$ elevation. Because Tapoca is a cooperative climate station, it records only maximum and minimum temperature and precipitation. Wind speed, relative humidity, atmospheric pressure, cloud cover, and dewpoint temperature were obtained from Coweeta's CS28. We used these combined data sets to calculate average annual daily means for the 10 -yr climate record from 1989 to 1998 . We used atmospheric deposition data from wet deposition (wetfall) and dry deposition (dryfall) collections taken at Coweeta for the same 10 -yr period.

For SR, climate data was obtained from Pisgah, NC (NCDC/ NOAA climate station no. 316805 ), located at $35.16^{\circ} \mathrm{N}$ lat, $83.42^{\circ} \mathrm{W}$ long, and $645 \mathrm{~m}$ elevation; approximately $16 \mathrm{~km}$ southeast of the sample plots. For LG, precipitation data was obtained from Banner Elk, NC (NCDC/NOAA climate station no. 310506 ), located at $36.09^{\circ} \mathrm{N}$ lat, $81.52^{\circ} \mathrm{W}$ long, and $1142 \mathrm{~m}$ elevation. Maximum and minimum temperature, wind speed, dew point, and cloud cover were obtained from Jefferson, NC (NCDC/NOAA, climate station no. 314496), located at $36.25^{\circ} \mathrm{N}$ lat, $81.26^{\circ} \mathrm{W}$ long, and $845 \mathrm{~m}$ elevation. Banner Elk is located about $14 \mathrm{~km}$ and Jefferson is about $70 \mathrm{~km}$ north of Linville Gorge. Banner Elk only collected precipitation, but its precipitation would be more similar to that received at Linville Gorge. Jefferson was the closest climate station with a full climate record. For SR and LG, we used average annual daily means for the 10-yr climate record from 1992 to 2001.

For both SR and LG, we used atmospheric deposition data, bulk deposition wetfall and dryfall, for a 10 -yr period (1992-2001), supplied from National Atmospheric Deposition Program (National Atmospheric Deposition Program, 1998) site NC45 located at Mt. Mitchell, NC. Mt. Mitchell is the closest NADP site to these two wilderness areas and it is also a high elevation site $(1900 \mathrm{~m})$. Wet deposition (wetfall) and dry deposition (dryfall) were calculated from a ratio of wetfall/dryfall based on the long-term record at Coweeta Hydrologic Laboratory. Soil temperature data were calculated from air temperature data using a model developed for the Coweeta Basin (Vose and Swank, 1991); monthly average values were calculated for each of the soil depths used in the simulations. Physiographic data included stand physical characteristics, soil physical characteristics, soil chemistry, and stream chemistry and characteristics. In $\mathrm{NuCM}$, mineral weathering is calculated based on the dissolution of primary minerals when they react with hydrogen ions to form sec- ondary minerals plus cations and silica. These are slow reactions that depend on the mass of the mineral and solution-phase of hydrogen-ion concentration taken to a fractional power (Munsen et al., 1992). For the mineral composition and mass, we used generalized values for all three wilderness areas that represented the most common metamorphic geology of the region (Velbel, 1992). Once compiled, these data were input using the format outlined in the NuCM user's manual (Munsen et al., 1992).

\section{Stream, Soil Solution, and Soil Chemistry}

At all three study areas, water samples were collected from streams that drain study plot locations. At JK, we collected samples from four first-order streams that drain into Little Santeetlah Creek. At SR, we collected samples at five first order streams that drain into Greasy Cove Prong Creek. At LG, we collected samples at five locations along a first-order stream that drains into the Linville River. Calcium, $\mathrm{K}, \mathrm{Mg}, \mathrm{Na}$, and $\mathrm{NH}_{4}$, and extractable $\mathrm{SO}_{4}$, $\mathrm{HPO}_{4}, \mathrm{NO}_{3}$, and $\mathrm{pH}$ were analyzed at the Coweeta Hydrologic Analytical Lab, Otto, NC. Concentrations of $\mathrm{Ca}, \mathrm{Mg}, \mathrm{K}$, and $\mathrm{Na}$ were determined using a PerkinElmer Analyst 300 atomic absorption spectrophotometer (PerkinElmer Corp., Norwalk, CN). Nitrate, $\mathrm{SO}_{4}$, and $\mathrm{HPO}_{4}$ were determined using a Dionex ion chromatograph (Dionex Corp., Sunnyvale, CA). Ammonium-N was determined with an Alpkem Perstorp autoanalyzer (Alpkem Corp., Wilsonville, OR) using the alkaline phenol (USEPA, 1983a) techniques, respectively. Aluminum and dissolved organic carbon (DOC) were analyzed at the Riverbend Analytical Laboratory of University of Georgia, Athens. For Al, water samples were composited monthly and preserved with HCL acid to a pH of 2.0. Analysis was performed on a VG Inductively Coupled Plasma Mass Spectrometer (PerkinElmer SCIEX, Norwalk, CT) using Standard Methods (APHA, 2000). For DOC, stream water samples were filtered through $0.45 \mu \mathrm{m}$-pore-diameter-filters, and analysis was performed on an Ol-Analytical TOC analyzer (College Station, TX) using standard methods (APHA, 2000).

Soil solution samples were obtained by installing porous cup tension lysimeters on each plot at each of the sites (i.e., three plots at JK; five plots at SR; and five plots at LG). Lysimeters were placed at depths representing the bottom of the dominant soil horizons of each site, generally the $\mathrm{A}, \mathrm{AB}$ or $\mathrm{BA}$, and $\mathrm{B}$ horizons. Horizon depths were identified from Natural Resources Conservation Service soil survey information (USDA-NRCS, 1996) and by soil probe reconnaissance at each site (Jennifer Knoepp, personal observations, 2000). Lysimeters were installed at 10,60 , and $90 \mathrm{~cm}$ for $\mathrm{JK} ; 20,60$, and $90 \mathrm{~cm}$ for SR; and 15,35 , and $65 \mathrm{~cm}$ for LG. Two sets of lysimeters were installed on each plot at all sites at randomly selected locations (i.e., a total of 18 lysimeters at JK, and 30 lysimeters at SR and LG). Soil water and stream water samples were collected weekly and composited to obtain a monthly sample. Samples were collected for a 6 to $8 \mathrm{mo}$ period in $1999-2000$ for JK, 2000 for SR, and 2001-2002 for LG. Analytical procedures for soil water were the same as described for stream water samples.

Composite soil samples were collected from all plots within JK, SR, and LG. Soils on each plot were collected by depth, using an Oakfield soil probe. Depths correspond to major soil 
horizons as described above. Actual sample depths were 0 to 10 , 10 to 30 , and 30 to $90 \mathrm{~cm}$ for JK; 0 to 20,20 to 60 , and 60 to $90 \mathrm{~cm}$ for SR; and 0 to 15,15 to 35 , and 35 to $65 \mathrm{~cm}$ for LG. Composite samples were made up of six to eight individual samples. Soils were kept cool until returned to the laboratory and then stored at $4^{\circ} \mathrm{C}$. Within $24 \mathrm{~h}$, soils were moist sieved to $<6$ $\mathrm{mm}$ and extracted with $2 \mathrm{M} \mathrm{KCl}$ for determination of $\mathrm{NO}_{3}-$ and $\mathrm{NH}_{4}-\mathrm{N}$. One 5-g subsample was shaken with $20 \mathrm{~mL}$ of $2 \mathrm{M}$ $\mathrm{KCl}$ for $1 \mathrm{~h}$ to extract $\mathrm{NH}_{4}-$ and $\mathrm{NO}_{3}-\mathrm{N}$. The soil/ $\mathrm{KCl}$ mixture was then centrifuged for $15 \mathrm{~min}$ at $6000 \mathrm{rpm}$. The supernatant was analyzed for $\mathrm{NH}_{4}$ - and $\mathrm{NO}_{3}-\mathrm{N}$ on an Alpkem Perstorp autoanalyzer (Alpkem Corp., Wilsonville, OR) using alkaline phenol (USEPA, 1983a) and cadmium reduction (USEPA, 1983b) techniques, respectively. One subsample $(10 \mathrm{~g})$ was placed in a $105^{\circ} \mathrm{C}$ oven for $>12 \mathrm{~h}$ to obtain oven-dry weight. All soil $\mathrm{N}$ data are reported on an oven dry weight basis. All soil data are presented for sample depth and horizon designations as described above but are referred to as $A, A B$, and $B$ horizons.

Soil samples were air-dried and sieved to $<2 \mathrm{~mm}$ before chemical analysis. Exchangeable cations were extracted from 10 $\mathrm{g}$ of soil on a mechanical vacuum soil extractor using $50 \mathrm{~mL}$ of 1 $\mathrm{M} \mathrm{NH}_{4} \mathrm{Cl}$. Solution concentrations of $\mathrm{Ca}, \mathrm{Mg}, \mathrm{K}$, and $\mathrm{Na}$ were determined using a PerkinElmer atomic absorption spectrometer (PerkinElmer Corp., Norwalk, CN). Aluminum was determined with a Thermo Jarrell-Ash Enviro 36 Inductively Coupled Argon Plasma (standard methods; APHA, 2000) at the University of Georgia, Chemical Analysis Laboratory, Athens, GA. Following the initial 12-h extraction excess $\mathrm{NH}_{4} \mathrm{Cl}$ was removed from the soil interstitial spaces with $95 \% \mathrm{EtOH}$. Ammonium-N on the soil exchange sites was then extracted with $2 \mathrm{M} \mathrm{KCl}$ as a measure of effective soil cation exchange capacity (ECEC). The $\mathrm{NH}_{4}-\mathrm{N}$ concentration in the $\mathrm{KCl}$ solution was determined using the alkaline phenol method described above. Soil $\mathrm{pH}$ was determined in a $1: 1$ soil/ $0.01 \mathrm{M} \mathrm{CaCl}_{2}$ solution slurry. We used analysis of variance (PROC GLM, SAS Institute, 2002-2003) to determine significant differences for stream, soil solution, and soil chemistry among the three wilderness areas.

Langmuir $\mathrm{SO}_{4}$ adsorption isotherms were generated for each soil sample using the method outlined by Harrison et al. (1989), with slight modifications. We used $5 \mathrm{~g}$ of air-dry soil placed in a mechanical soil extractor and $50 \mathrm{~mL}$ of solution for both desorption and adsorption phases. For native $\mathrm{SO}_{4}$ desorption, soil was extracted repeatedly with deionized $\mathrm{H}_{2} \mathrm{O}$ to remove native $\mathrm{SO}_{4}$ and obtain a desorption curve. The desorption phase continued until the $\mathrm{SO}_{4}$ concentrations in the extract solution was $<0.005$ $\mathrm{mmol}_{\mathrm{c}} \mathrm{L}^{-1}$, about 10 extractions. Irreversibly adsorbed native $\mathrm{SO}_{4}$ was then extracted from the same soil sample with five $50-\mathrm{mL}$ aliquots of $5.26 \mathrm{mmol}_{c} \mathrm{~L}^{-1} \mathrm{~K}_{2} \mathrm{HPO}_{4}$ solution. The $\mathrm{SO}_{4}$ desorbed from the soil plus the $\mathrm{K}_{2} \mathrm{HPO}_{4}$ extracted $\mathrm{SO}_{4}$ was summed to determine native $\mathrm{SO}_{4}$ concentrations. For $\mathrm{SO}_{4}$ adsorption, 50 $\mathrm{mL}$ of $\mathrm{CaSO}_{4}$ solution was repeatedly leached through $5.0 \mathrm{~g}$ soil aliquots to obtain data for calculating $\mathrm{S} \mathrm{SO}_{4}$ adsorption curve.

Solution concentrations ranged from 0.05 to $0.25 \mathrm{mM}$ $\mathrm{CaSO}_{4}$ and differed for each site: Shining Rock, 0.05, 0.08, and $0.25 \mathrm{mmol}$; Linville Gorge, $0.08,0.15$, and $0.25 \mathrm{mmol}$; and Joyce Kilmer, $0.08,0.15$, and $0.25 \mathrm{mmol}$. Initially, we used the
$0.25 \mathrm{mmol}$ solution recommended by Harrison et al. (1989) for isotherm determination using one 5-g soil sample, conducting a minimum of 10 extractions. The amount of $\mathrm{SO}_{4}$ adsorbed increased slowly; however, solution concentrations equilibrated quickly, often after only two extraction cycles leaving few points to generate the Langmuir isotherm. Therefore, we applied two lower concentration solutions (see concentrations above); on a second 5-g soil sample, to $\mathrm{SO}_{4}$ define the lower portion of the adsorption curve. The second soil sample was leached sequentially, five times with the lowest and five times with the middle solution concentration. Sulfate concentrations in all solutions were determined on a Dionex ion chromatograph (Dionex Corp., Sunnyvale, CA). All equilibrium solution concentrations were corrected for interstitial solution $\mathrm{SO}_{4}-\mathrm{S}$.

We calculated the Langmuir isotherms using both desorption and adsorption data with PROC NLIN (SAS Institute, 2002-2003), to solve the equation $X=A B C /(1+B C)$, where $X=\mathrm{SO}_{4}$ adsorbed $\left(\mu \mathrm{mol}_{\mathrm{c}} \mathrm{kg}^{-1}\right)$ by the soil; $A=$ adsorption maximum ( $\left.\mu \mathrm{mol}_{\mathrm{c}} \mathrm{kg}^{-1}\right) ; B=$ adsorption coefficient; and $C=$ equilibrium $\mathrm{SO}_{4}-\mathrm{S}$ concentration $\left(\mu \mathrm{mol}_{c} \mathrm{~L}^{-1}\right)$ in solution.

\section{Biomass}

We estimated biomass of the overstory, understory, forest floor, and roots from 20 by $20 \mathrm{~m}$ plots located in each of the wilderness areas. In the plots, diameter of all woody stems was measured to the nearest $0.1 \mathrm{~cm}$. To estimate aboveground biomass, diameter measurements were converted to biomass using species-specific allometric equations from Martin et al. (1999) for the hardwoods and Jenkins et al. (2003) for the pines. Four forest floor samples were collected within each plot at each site using a 0.3 by $0.3-\mathrm{m}$ wooden sampling frame. Material within the $0.09-\mathrm{m}^{2}$ quadrat was separated into three components: small wood $(<7.5 \mathrm{~cm}$ diameter), litter $(\mathrm{Oi})$, and a combined fermentation and humus layer $(\mathrm{Oe}+$ Oa). Small wood within the sampling frame was cut using pruning shears, and forest floor was removed by component (i.e., Oi, $\mathrm{Oe}+\mathrm{Oa}$ ) after cutting along the inside of the sampling frame with a knife. Forest floor materials were placed in a paper bag and transported to the laboratory. Root mass was estimated by taking five cores from each plot. Root cores were $5.1 \mathrm{~cm}$ in diameter and samples were collected from mineral soil to $30 \mathrm{~cm}$. Forest floor and root samples were dried at least $72 \mathrm{~h}$ at $60^{\circ} \mathrm{C}$, to a constant weight, and weighed to the nearest $0.1 \mathrm{~g}$. Aboveground live biomass and root biomass estimated values were then input into the $\mathrm{NuCM}$ model for simulations for each site.

\section{Calibration of The Nutrient Cycling Model}

The NuCM was calibrated using data collected from JK, SR, and LG, the NCDC/NOAA climate records, and long-term records at Coweeta according to the procedures outlined in the user's manual (Munsen et al., 1992) and guidelines presented by Johnson et al. (1993) for a mixed deciduous forest in the Coweeta Basin. During the process of calibration, soil hydraulic conductivity, the "evapotranspiration coefficient," and saturated hydraulic conductivities were used to match model output with known evapotranspiration rates, soil water flux, and lateral flow values from Coweeta Hydrologic Laboratory (Johnson et al., 1993). In 
Table 2. Species composition, density (stems ha-1) and basal area (BA; $\mathbf{m}^{2} \mathbf{h a}^{-1}$ ) of the overstory (stems $\geq 5.1 \mathrm{~cm} \mathrm{dbh}$ ) and understory (stems $<5.1 \mathrm{~cm} \mathrm{dbh}$ $>0.5 \mathrm{~m}$ height) for three Class I wilderness areas (Joyce Kilmer/Slickrock, Shining Rock, and Linville Gorge) in western North Carolina, United States. Species are ordered by descending basal area.

\begin{tabular}{|c|c|c|c|c|c|}
\hline Overstoryt & Density & BA & Understoryt & Density & BA \\
\hline \multicolumn{6}{|c|}{ Joyce Kilmer $\neq$} \\
\hline Tulip poplar & 29 & 12.28 & Black birch & 65 & 0.069 \\
\hline Northern red oak & 42 & 8.18 & Eastern hemlock & 47 & 0.057 \\
\hline Sugar maple & 120 & 8.14 & American beech & 38 & 0.040 \\
\hline Eastern hemlock & 236 & 6.68 & Sugar maple & 33 & 0.030 \\
\hline Red maple & 71 & 5.83 & Striped maple & 13 & 0.022 \\
\hline Chestnut oak & 20 & 5.52 & Red maple & 18 & 0.016 \\
\hline Sourwood & 22 & 4.33 & Fraser magnolia & 9 & 0.013 \\
\hline Hickory & 9 & 3.62 & Ironwood & 13 & 0.009 \\
\hline Black birch & 91 & 3.48 & Yellow birch & 7 & 0.006 \\
\hline Silverbell & 89 & 3.23 & Cucumber tree & 4 & 0.004 \\
\hline American beech & 67 & 2.02 & Mountain holly & 4 & 0.003 \\
\hline Cucumber tree & 9 & 1.52 & Silverbell & 2 & 0.002 \\
\hline Basswood & 7 & 1.01 & Buckeye & 2 & 0.001 \\
\hline Yellow birch & 38 & 0.73 & Serviceberry & 2 & 0.001 \\
\hline Striped maple & 20 & 0.32 & & & \\
\hline Fraser magnolia & 20 & 0.10 & & & \\
\hline Serviceberry & 2 & 0.06 & & & \\
\hline Flowering dogwood & 2 & 0.01 & & & \\
\hline \multicolumn{6}{|c|}{ Shining Rock } \\
\hline Yellow birch & 280 & 4.22 & Rose bay & 715 & 1.42 \\
\hline Red maple & 45 & 2.64 & Highbush blueberry & 225 & 0.16 \\
\hline Mountain holly & 700 & 2.40 & Mountain holly & 380 & 0.14 \\
\hline Pin cherry & 245 & 2.37 & Flame azalea & 220 & 0.07 \\
\hline Serviceberry & 55 & 0.75 & Mountain rosebay & 90 & 0.08 \\
\hline Red spruce & 5 & 0.53 & Pepperbush & 170 & 0.05 \\
\hline Sugar maple & 5 & 0.38 & Yellow birch & 55 & 0.02 \\
\hline Black birch & 5 & 0.12 & Mountain laurel & 10 & 0.04 \\
\hline Mountain maple & 5 & 0.02 & Witherod & 20 & $<0.01$ \\
\hline & & & Highbush blackberry & 20 & $<0.01$ \\
\hline & & & Pin cherry & 10 & $<0.01$ \\
\hline \multicolumn{6}{|c|}{ Linville Gorge } \\
\hline Chestnut oak & 90 & 6.15 & Rose bay & 450 & 0.42 \\
\hline Pitch pine & 50 & 5.26 & Mountain laurel & 380 & 0.36 \\
\hline White pine & 35 & 4.15 & Maleberry & 245 & 0.07 \\
\hline Red maple & 110 & 2.54 & Eastern hemlock & 40 & 0.01 \\
\hline Sourwood & 185 & 2.51 & Sourwood & 35 & 0.01 \\
\hline Blackgum & 135 & 2.30 & Horsesugar & 20 & 0.01 \\
\hline Sassafras & 190 & 2.10 & White pine & 5 & 0.01 \\
\hline Eastern hemlock & 25 & 2.01 & Blackgum & 5 & 0.01 \\
\hline Fraser magnolia & 10 & 0.36 & Serviceberry & 5 & 0.01 \\
\hline Scarlet oak & 10 & 0.30 & Sassafras & 15 & $<0.01$ \\
\hline Witch hazel & 55 & 0.22 & Red maple & 5 & $<0.01$ \\
\hline Serviceberry & 15 & 0.19 & Mountain rosebay & 5 & $<0.01$ \\
\hline American chestnut & 15 & 0.09 & Witch hazel & 5 & $<0.01$ \\
\hline Horsesugar & 10 & 0.04 & & & \\
\hline Northern red oak & 5 & 0.02 & & & \\
\hline
\end{tabular}

this study, we compared NuCM model simulation results for the three wilderness areas to a mixed deciduous forest in the Coweeta Basin $\left(35^{\circ} 04^{\prime} \mathrm{N}\right.$ lat, $83^{\circ} 26^{\prime} \mathrm{W}$ long). The Coweeta site is representative of most southern Appalachian forests, which are aggrading mixed deciduous vegetation, moderately acidic and low $\mathrm{N}$ soils that have a high $\mathrm{SO}_{4}$ adsorption capacity (Swank and Waide, 1988, Johnson et al., 1993). The Coweeta system strongly retains both $\mathrm{S}$ and $\mathrm{N}$ from atmospheric deposition (Swank and Waide, 1988; Johnson and Lindberg, 1991). Deposition of acidic ions $\left(\mathrm{SO}_{4}{ }^{2-}\right.$ and $\left.\mathrm{NO}_{3}{ }^{-}\right)$ is lower at Coweeta compared with other high-elevation sites such as Nolan Divide in the Smoky Mountains National Park (National Atmospheric Deposition Program, 1998; Johnson et al., 1999) or other industrialized regions in the eastern United States (National Atmospheric Deposition Program, 1998). Simulated effects of altered acidic atmospheric deposition on nutrient cycling at Coweeta have been summarized in previous papers (Johnson et al., 1993, 1995, 1999).

\section{Results and Discussion}

The three wilderness areas differed in forest structure, species composition (Table 2), and disturbance history. Joyce Kilmer/ Slickrock was dominated by tulip poplar (Liriodendron tulipifera L.), northern red oak (Quercus rubra L.), sugar maple (Acer saccharum Marshall), and eastern hemlock [Tsuga canadensis (L.) Carrière] with a sparse understory (Table 2), that has remained undisturbed during the past century. Shining Rock was dominated by yellow birch (Betula alleghaniensis Britton), red maple (Acer rubrum L.), mountain holly [Ilex montana (T.\&G.) A. Gray], and pin cherry (Prunus pensylvanica L.) with a dense understory of evergreen and deciduous $R$ hododendron species. For SR, the last large-scale disturbance in 1942, a stand replacing fire, initiated the conversion from a red spruce-dominated forest to the present forest composition and structure (Vanderzanden et al., 1999). Currently, the forest is comprised of northern hardwoods species that have a windswept character, low stature and multiple branching pattern, and red spruce is only a minor component of the forest community (Table 2). Linville Gorge was dominated by chestnut oak (Quercus prinus L.), pitch pine (Pinus rigida Miller), white pine (Pinus strobus L.), red maple, and sourwood [Oxydendrum arboreum (L.) DC.] with a less dense understory of evergreen rosebay rhododendron ( $R$ hododendron maximum L.) and mountain laurel (Kalmia latifolia L.) than SR (Table 2). Joyce Kilmer/Slickrock had the greatest aboveground live biomass; LG had the second greatest aboveg-

† Latin names for species are: red maple (Acer rubrum L.), striped maple (Acer pensylvanicum L.), sugar maple (Acer saccharum Marshall), mountain maple (Acer spicatum Lam.), buckeye (Aesculus octandra Marshall), serviceberry (Amelanchier laevis Wieg.), yellow birch (Betula alleghaniensis Britton), black birch (Betula lenta L.), iron wood (Carpinus caroliniana Walter), hickories (Carya spp.), American chestnut [Castanea dentata (Marshall) Borkh.], pepperbush (Clethra acuminata Michx.), flowering dogwood (Cornus florida L.), American beech (Fagus grandifolia Ehrh.), silverbell (Halesia carolina L.), witch hazel (Hamamelis virginiana L.), mountain holly [llex montana (T.\& G.) A. Gray], mountain laurel (Kalmia latifolia L.), tulip poplar (Liriodendron tulipifera L.), maleberry [Lyonia ligustrina (L.) DC.], cucumber tree (Magnolia acuminata L.), fraser magnolia (Magnolia fraseri Walter), blackgum (Nyssa sylvatica Marshall), sourwood [Oxydendrum arboretum (L.) DC.], red spruce (Picea rubens Sarg.), pitch pine (Pinus rigida Miller), white pine (Pinus strobus L.), pin cherry (Prunus pensylvanica L.), scarlet oak (Quercus coccinea Muenchh.), chestnut oak (Quercus prinus L.), northern red oak (Quercus rubra L.), flame azalea [Rhododendron calendulaceum (Michx.) Torr.], mountain rosebay (Rhododendron catawbiense Michx.), rose bay (Rhododendron maximum L.), blackberry (Rubus argutus Link.), sassafras [Sassafras albidum (Nutt.) Nees.], horsesugar [Symplocus tinctoria (L.) L'Hér], basswood (Tilia americana L.), eastern hemlock [Tsuga canadensis (L.) Carr.], highbush blueberry (Vaccinium simulatum L.), and witherod [Viburnum cassinoides (L.) T. \& G.].

\# For soyce Kilmer, only understory stems $>1.4 \mathrm{~m}$ in height were measured ( $\mathrm{dbh}$ range $2.5-5.0 \mathrm{~cm}$ ). 
Table 3. Soil chemistry for three Class I wilderness areas: Joyce Kilmer/Slickrock wilderness (JK), Shining Rock wilderness (SR), and Linville Gorge wilderness (LG) in western North Carolina, United States. All concentrations are in $\mathrm{cmol}_{\mathrm{c}} \mathrm{kg}^{-1}$ except soil pH.

\begin{tabular}{|c|c|c|c|c|c|c|c|c|c|}
\hline \multirow[b]{2}{*}{ Soil chemistry } & \multicolumn{3}{|c|}{ Depth 1 (A-horizon) $\ddagger$} & \multicolumn{3}{|c|}{ Depth 2+ (AB-horizon) $\div$} & \multicolumn{3}{|c|}{ Depth 3+ (B-horizon) $\ddagger$} \\
\hline & JKt & SR & LG & JK & SR & LG & JK & SR & LG \\
\hline $\mathrm{pH}$ & $\begin{array}{l}4.27 a \\
(0.14) \S\end{array}$ & $\begin{array}{l}3.41 \mathrm{~b} \\
(0.14)\end{array}$ & $\begin{array}{l}3.45 \mathrm{~b} \\
(0.15)\end{array}$ & $\begin{array}{l}4.36 a \\
(0.03\end{array}$ & $\begin{array}{l}3.85 \mathrm{~b} \\
(0.06)\end{array}$ & $\begin{array}{l}3.91 \mathrm{~b} \\
(0.09)\end{array}$ & $\begin{array}{l}4.44 a \\
(0.03)\end{array}$ & $\begin{array}{l}4.11 \mathrm{~b} \\
(0.08)\end{array}$ & $\begin{array}{l}3.95 \mathrm{~b} \\
(0.07)\end{array}$ \\
\hline $\mathrm{NO}_{3}{ }^{-}-\mathrm{N}$ & $\begin{array}{l}0.0013 \\
(0.0004)\end{array}$ & $\begin{array}{l}0.0031 \\
(0.0018)\end{array}$ & $\begin{array}{l}0.0003 \\
(0.0003)\end{array}$ & $\begin{array}{l}0.0002 \\
(0.0001)\end{array}$ & $\begin{array}{l}0.0009 \\
(0.0005)\end{array}$ & $\begin{array}{l}0.0003 \\
(0.0003)\end{array}$ & $\begin{array}{l}0.0002 \\
(0.0001)\end{array}$ & $\begin{array}{l}0.0003 \\
(0.0002)\end{array}$ & $\begin{array}{l}0.0002 \\
(0.0001)\end{array}$ \\
\hline $\mathrm{NH}_{4}^{+}-\mathrm{N}$ & $\begin{array}{l}0.016 \mathrm{ab} \\
(0.0025)\end{array}$ & $\begin{array}{l}0.024 \mathrm{a} \\
(0.0079)\end{array}$ & $\begin{array}{l}0.005 \mathrm{~b} \\
(0.0006)\end{array}$ & $\begin{array}{l}0.009 \mathrm{~b} \\
(0.0011)\end{array}$ & $\begin{array}{l}0.018 a \\
(0.0052)\end{array}$ & $\begin{array}{l}0.006 \mathrm{~b} \\
(0.0008)\end{array}$ & $\begin{array}{l}0.004 \mathrm{~b} \\
(0.0008)\end{array}$ & $\begin{array}{l}0.013 a \\
(0.0024)\end{array}$ & $\begin{array}{l}0.004 \mathrm{~b} \\
(0.0004)\end{array}$ \\
\hline $\mathrm{HPO}_{4}{ }^{2-}$ & $\begin{array}{l}0.004 \\
(0.0009)\end{array}$ & $\begin{array}{l}0.010 \\
(0.0028)\end{array}$ & $\begin{array}{l}0.011 \\
(0.0028)\end{array}$ & $\begin{array}{l}0.003 \\
(0.0002)\end{array}$ & $\begin{array}{l}0.003 \\
(0.0005)\end{array}$ & $\begin{array}{l}0.004 \\
(0.0009)\end{array}$ & $\begin{array}{l}0.004 \\
(0.0007)\end{array}$ & $\begin{array}{l}0.003 \\
(0.0007)\end{array}$ & $\begin{array}{l}0.003 \\
(0.0006)\end{array}$ \\
\hline $\mathrm{K}^{+}$ & $\begin{array}{l}0.402 a \\
(0.038)\end{array}$ & $\begin{array}{l}0.162 \mathrm{~b} \\
(0.021)\end{array}$ & $\begin{array}{l}0.116 b \\
(0.013)\end{array}$ & $\begin{array}{l}0.169 a \\
(0.020)\end{array}$ & $\begin{array}{l}0.090 \mathrm{~b} \\
(0.014)\end{array}$ & $\begin{array}{l}0.082 \mathrm{~b} \\
(0.008)\end{array}$ & $\begin{array}{l}0.113 \\
(0.024)\end{array}$ & $\begin{array}{l}0.059 \\
(0.006)\end{array}$ & $\begin{array}{l}0.063 \\
(0.006)\end{array}$ \\
\hline $\mathrm{Na}^{+}$ & $\begin{array}{l}0.080 a \\
(0.018)\end{array}$ & $\begin{array}{l}0.018 b \\
(0.003)\end{array}$ & $\begin{array}{l}0.009 \mathrm{~b} \\
(0.0006)\end{array}$ & $\begin{array}{l}0.018 \\
(0.012)\end{array}$ & $\begin{array}{l}0.016 \\
(0.001)\end{array}$ & $\begin{array}{l}0.007 \\
(0.0004)\end{array}$ & $\begin{array}{l}0.013 \\
(0.009)\end{array}$ & $\begin{array}{l}0.014 \\
(0.001)\end{array}$ & $\begin{array}{l}0.006 \\
(0.0005)\end{array}$ \\
\hline $\mathrm{Ca}^{2+}$ & $\begin{array}{l}2.310 a \\
(0.717)\end{array}$ & $\begin{array}{l}0.451 \mathrm{~b} \\
(0.070)\end{array}$ & $\begin{array}{l}0.039 \mathrm{~b} \\
(0.005)\end{array}$ & $\begin{array}{l}0.433 a \\
(0.168)\end{array}$ & $\begin{array}{l}0.161 \mathrm{~b} \\
(0.030)\end{array}$ & $\begin{array}{l}0.022 \mathrm{~b} \\
(0.004)\end{array}$ & $\begin{array}{l}0.155 a \\
(0.047)\end{array}$ & $\begin{array}{l}0.099 \mathrm{ab} \\
(0.020)\end{array}$ & $\begin{array}{l}0.018 b \\
(0.006)\end{array}$ \\
\hline $\mathrm{Mg}^{2+}$ & $\begin{array}{l}0.933 \mathrm{a} \\
(0.216)\end{array}$ & $\begin{array}{l}0.303 \mathrm{~b} \\
(0.068)\end{array}$ & $\begin{array}{l}0.093 c \\
(0.007)\end{array}$ & $\begin{array}{l}0.146 \mathrm{a} \\
(0.027)\end{array}$ & $\begin{array}{l}0.109 a \\
(0.006)\end{array}$ & $\begin{array}{l}0.043 \mathrm{~b} \\
(0.003)\end{array}$ & $\begin{array}{l}0.087 \mathrm{a} \\
(0.016)\end{array}$ & $\begin{array}{l}0.060 \mathrm{ab} \\
(0.004)\end{array}$ & $\begin{array}{l}0.030 \mathrm{~b} \\
(0.004)\end{array}$ \\
\hline $\mathrm{SO}_{4}^{2-}$ & $\begin{array}{l}0.200 \\
(0.044)\end{array}$ & $\begin{array}{l}0.187 \\
(0.006)\end{array}$ & $\begin{array}{l}0.305 \\
(0.104)\end{array}$ & $\begin{array}{l}0.521 \\
(0.129)\end{array}$ & $\begin{array}{l}0.328 \\
(0.012)\end{array}$ & $\begin{array}{l}0.556 \\
(0.156)\end{array}$ & $\begin{array}{l}0.946 \mathrm{a} \\
(0.188)\end{array}$ & $\begin{array}{l}0.437 b \\
(0.008)\end{array}$ & $\begin{array}{l}0.404 b \\
(0.134)\end{array}$ \\
\hline $\mathrm{Al}^{3+}$ & $\begin{array}{l}3.357 \\
(1.157)\end{array}$ & $\begin{array}{l}5.490 \\
(1.316)\end{array}$ & $\begin{array}{l}5.935 \\
(0.658)\end{array}$ & $\begin{array}{l}3.109 a \\
(0.390)\end{array}$ & $\begin{array}{l}5.329 b \\
(0.408)\end{array}$ & $\begin{array}{l}4.760 \mathrm{~b} \\
(0.473)\end{array}$ & $\begin{array}{l}2.996 \\
(0.350)\end{array}$ & $\begin{array}{l}3.588 \\
(0.757)\end{array}$ & $\begin{array}{l}4.430 \\
(0.571)\end{array}$ \\
\hline ECEC & $\begin{array}{l}17.98 \mathrm{a} \\
(2.37)\end{array}$ & $\begin{array}{l}11.06 \mathrm{~b} \\
(1.64)\end{array}$ & $\begin{array}{l}6.84 \mathrm{~b} \\
(0.23)\end{array}$ & $\begin{array}{l}11.03 \mathrm{a} \\
(0.79)\end{array}$ & $\begin{array}{l}10.29 a \\
(0.66)\end{array}$ & $\begin{array}{l}6.81 \mathrm{~b} \\
(0.40)\end{array}$ & $\begin{array}{l}8.69 a \\
(0.70)\end{array}$ & $\begin{array}{l}7.85 a \\
(0.56) \\
\end{array}$ & $\begin{array}{l}5.46 \mathrm{~b} \\
(0.62)\end{array}$ \\
\hline
\end{tabular}

† Within a soil depth, values followed by different letters denote a significant difference $(p<0.05)$ among sites (SAS Institute, 2002-2003).

¥ Standard errors are in parentheses.

$\S$ For JK, soil depths were $0-10 \mathrm{~cm}, 10-30 \mathrm{~cm}$, and $30-90 \mathrm{~cm}$; for $S R$, soil depths were 0-20 cm, 20-60 cm and 60-90 cm; and for LG, soil depths were $0-15 \mathrm{~cm}, 15-35 \mathrm{~cm}$, and $35-65 \mathrm{~cm}$.

round live biomass with Pinus species contributing a large proportion of the biomass; and SR had the least aboveground live biomass (Table 2). The presence of the Pinus species at LG contributed to the accumulation of forest floor mass (Table 1). The recalcitrant evergreen litter at both SR and LG may have contributed to the soil and soil solution acidity at these sites (Tables 3 and 4).

Table 4. Mean soil solution and stream chemistry for three Class I wilderness areas: Joyce Kilmer/Slickrock wildness (JK), Shining Rock wilderness (SR), and Linville Gorge wilderness (LG) in western North Carolina, United States. All values are in $\mu_{m o l} \mathrm{~L}^{-1}$ except for $\left.\mathrm{pH}_{,} \mathrm{Al}_{(\mathrm{mg} \mathrm{L}} \mathrm{L}^{-1}\right)$ and DOC (mg L-1).

\begin{tabular}{|c|c|c|c|c|c|c|c|c|c|c|c|c|}
\hline \multirow[b]{3}{*}{ Soil chemistry } & \multicolumn{9}{|c|}{ Soil solution chemistry } & & & \\
\hline & \multicolumn{3}{|c|}{ Depth 1t (A-horizon) $\ddagger$} & \multicolumn{3}{|c|}{ Depth 2† (AB-horizon) $\ddagger$} & \multicolumn{3}{|c|}{ Depth $3+$ (B-horizon) $\ddagger$} & \multicolumn{3}{|c|}{ Streamt } \\
\hline & JK & SR & LG & JK & SR & LG & JK & SR & LG & JK & SR & LG \\
\hline$\overline{\mathrm{pH}}$ & $\begin{array}{l}5.75 a \\
(0.25) \S\end{array}$ & $\begin{array}{l}4.35 \mathrm{~b} \\
(0.15)\end{array}$ & $\begin{array}{l}4.22 \mathrm{~b} \\
(0.12)\end{array}$ & $\begin{array}{l}5.43 a \\
(0.22)\end{array}$ & $\begin{array}{l}4.80 \mathrm{~b} \\
(0.11)\end{array}$ & $\begin{array}{l}4.40 \mathrm{~b} \\
(0.12)\end{array}$ & $\begin{array}{l}5.44 a \\
(0.14)\end{array}$ & $\begin{array}{l}5.04 \mathrm{~b} \\
(0.09)\end{array}$ & $\begin{array}{l}4.51 \mathrm{C} \\
(0.11)\end{array}$ & $\begin{array}{l}6.66 a \\
(0.08)\end{array}$ & $\begin{array}{l}6.08 \mathrm{~b} \\
(0.08)\end{array}$ & $\begin{array}{l}4.74 c \\
(0.04)\end{array}$ \\
\hline $\mathrm{NO}_{3}--\mathrm{N}$ & $\begin{array}{l}4.76 \\
(2.40)\end{array}$ & $\begin{array}{l}1.60 \\
(0.75)\end{array}$ & $\begin{array}{l}2.07 \\
(0.89)\end{array}$ & $\begin{array}{c}16.46 \mathrm{a} \\
(12.96)\end{array}$ & $\begin{array}{l}5.03 \mathrm{ab} \\
(1.75)\end{array}$ & $\begin{array}{l}0.48 \mathrm{~b} \\
(0.12)\end{array}$ & $\begin{array}{l}5.85 \\
(2.31)\end{array}$ & $\begin{array}{l}5.68 \\
(3.19)\end{array}$ & $\begin{array}{l}0.62 \\
(0.23)\end{array}$ & $\begin{array}{l}2.69 \mathrm{a} \\
(0.64)\end{array}$ & $\begin{array}{l}0.71 b \\
(0.12)\end{array}$ & $\begin{array}{l}2.06 \mathrm{a} \\
0.62)\end{array}$ \\
\hline $\mathrm{NH}_{4}{ }^{+}-\mathrm{N}$ & $\begin{array}{l}1.20 \\
(0.58)\end{array}$ & $\begin{array}{l}0.93 \\
(0.24)\end{array}$ & $\begin{array}{l}1.10 \\
(0.49)\end{array}$ & $\begin{array}{l}1.47 \\
(0.50)\end{array}$ & $\begin{array}{l}1.67 \\
(0.79)\end{array}$ & $\begin{array}{l}0.36 \\
(0.05)\end{array}$ & $\begin{array}{l}0.41 \\
(0.06)\end{array}$ & $\begin{array}{l}0.57 \\
(0.16)\end{array}$ & $\begin{array}{l}0.44 \\
(0.15)\end{array}$ & $\begin{array}{l}0.31 \mathrm{~b} \\
(0.03)\end{array}$ & $\begin{array}{l}0.35 b \\
(0.05)\end{array}$ & $\begin{array}{l}0.74 \mathrm{a} \\
(0.18)\end{array}$ \\
\hline $\mathrm{HPO}_{4}{ }^{2-}$ & $\begin{array}{l}0.12 \\
(0.07)\end{array}$ & $\begin{array}{l}0.17 \\
(0.04)\end{array}$ & $\begin{array}{l}0.23 \\
(0.08)\end{array}$ & $\begin{array}{l}0.09 \\
(0.06)\end{array}$ & $\begin{array}{l}0.09 \\
(0.02)\end{array}$ & $\begin{array}{l}0.08 \\
(0.01)\end{array}$ & $\begin{array}{l}0.10 \\
(0.06)\end{array}$ & $\begin{array}{l}0.06 \\
(0.01)\end{array}$ & $\begin{array}{l}0.12 \\
(0.01)\end{array}$ & $\begin{array}{l}0.09 \\
(0.03)\end{array}$ & $\begin{array}{l}0.12 \\
(0.02)\end{array}$ & $\begin{array}{l}0.10 \\
(0.01)\end{array}$ \\
\hline $\mathrm{Cl}^{-}$ & $\begin{array}{l}38.44 \\
(3.23)\end{array}$ & $\begin{array}{l}55.38 \\
(26.04)\end{array}$ & $\begin{array}{l}41.64 \\
(5.97)\end{array}$ & $\begin{array}{l}45.73 \\
(6.41)\end{array}$ & $\begin{array}{l}43.16 \\
(18.19)\end{array}$ & $\begin{array}{l}37.16 \\
(4.12)\end{array}$ & $\begin{array}{l}25.23 \\
(3.47)\end{array}$ & $\begin{array}{l}21.56 \\
(5.91)\end{array}$ & $\begin{array}{l}32.81 \\
(2.82)\end{array}$ & $\begin{array}{l}11.88 \mathrm{~b} \\
(0.27)\end{array}$ & $\begin{array}{l}7.99 \mathrm{C} \\
(0.22)\end{array}$ & $\begin{array}{l}25.44 \mathrm{a} \\
(2.34)\end{array}$ \\
\hline $\mathrm{K}^{+}$ & $\begin{array}{l}58.44 \mathrm{a} \\
(15.08)\end{array}$ & $\begin{array}{l}13.71 \mathrm{~b} \\
(2.84)\end{array}$ & $\begin{array}{l}42.74 \mathrm{a} \\
(8.05)\end{array}$ & $\begin{array}{l}21.82 \mathrm{a} \\
(9.70)\end{array}$ & $\begin{array}{l}6.08 \mathrm{~b} \\
(1.04)\end{array}$ & $\begin{array}{l}17.16 \mathrm{ab} \\
(2.98)\end{array}$ & $\begin{array}{l}6.44 \\
(1.16)\end{array}$ & $\begin{array}{l}4.17 \\
(0.68)\end{array}$ & $\begin{array}{l}9.68 \\
(2.39)\end{array}$ & $\begin{array}{l}9.82 \mathrm{a} \\
(0.69)\end{array}$ & $\begin{array}{l}5.29 \mathrm{C} \\
(0.12)\end{array}$ & $\begin{array}{l}7.35 \mathrm{~b} \\
(0.47)\end{array}$ \\
\hline $\mathrm{Na}^{+}$ & $\begin{array}{l}13.03 \\
(0.91)\end{array}$ & $\begin{array}{l}20.19 \\
(3.47)\end{array}$ & $\begin{array}{l}23.82 \\
(2.58)\end{array}$ & $\begin{array}{l}13.54 \mathrm{~b} \\
(1.73)\end{array}$ & $\begin{array}{l}16.47 \mathrm{~b} \\
(1.06)\end{array}$ & $\begin{array}{l}23.60 \mathrm{~b} \\
(2.26)\end{array}$ & $\begin{array}{l}14.74 \\
(0.79)\end{array}$ & $\begin{array}{l}17.15 \\
(1.21)\end{array}$ & $\begin{array}{l}17.69 \\
(1.55)\end{array}$ & $\begin{array}{l}41.54 \mathrm{a} \\
(4.41)\end{array}$ & $\begin{array}{l}25.62 b \\
(0.81)\end{array}$ & $\begin{array}{l}18.36 b \\
(0.99)\end{array}$ \\
\hline $\mathrm{Ca}^{2+}$ & $\begin{array}{l}73.05 a \\
(21.24)\end{array}$ & $\begin{array}{l}22.74 b \\
(5.26)\end{array}$ & $\begin{array}{l}17.56 \mathrm{~b} \\
(4.60)\end{array}$ & $\begin{array}{l}67.08 \mathrm{a} \\
(22.22)\end{array}$ & $\begin{array}{l}22.32 \mathrm{~b} \\
(4.04)\end{array}$ & $\begin{array}{l}9.17 b \\
(2.56)\end{array}$ & $\begin{array}{l}59.99 a \\
(16.48)\end{array}$ & $\begin{array}{l}17.66 \mathrm{~b} \\
(2.99)\end{array}$ & $\begin{array}{l}4.81 \mathrm{~b} \\
(1.98)\end{array}$ & $\begin{array}{l}39.13 a \\
(2.70)\end{array}$ & $\begin{array}{l}15.28 \mathrm{~b} \\
(2.03)\end{array}$ & $\begin{array}{l}13.80 \mathrm{~b} \\
(3.01)\end{array}$ \\
\hline $\mathrm{Mg}^{2+}$ & $\begin{array}{l}40.44 \\
(5.10)\end{array}$ & $\begin{array}{l}29.89 \\
(6.73)\end{array}$ & $\begin{array}{l}30.76 \\
(3.84)\end{array}$ & $\begin{array}{l}41.81 \mathrm{a} \\
(2.83)\end{array}$ & $\begin{array}{l}20.46 \mathrm{~b} \\
(1.83)\end{array}$ & $\begin{array}{l}22.45 \mathrm{~b} \\
(4.13)\end{array}$ & $\begin{array}{l}34.79 a \\
(6.01)\end{array}$ & $\begin{array}{l}19.50 \mathrm{~b} \\
(2.56)\end{array}$ & $\begin{array}{l}15.81 b \\
(3.45)\end{array}$ & $\begin{array}{l}21.97 \mathrm{a} \\
(2.13)\end{array}$ & $\begin{array}{l}12.15 b \\
(0.79)\end{array}$ & $\begin{array}{l}15.14 b \\
(1.16)\end{array}$ \\
\hline $\mathrm{SO}_{4}{ }^{2-}$ & $\begin{array}{l}117.9 \\
(20.77)\end{array}$ & $\begin{array}{l}64.18 \\
(22.50)\end{array}$ & $\begin{array}{l}99.98 \\
(7.63)\end{array}$ & $\begin{array}{l}98.72 \mathrm{a} \\
(10.34)\end{array}$ & $\begin{array}{l}42.34 \mathrm{~b} \\
(5.06)\end{array}$ & $\begin{array}{l}113.1 \mathrm{a} \\
(11.23)\end{array}$ & $\begin{array}{l}97.99 \mathrm{a} \\
(17.24)\end{array}$ & $\begin{array}{l}38.79 \mathrm{~b} \\
(4.16)\end{array}$ & $\begin{array}{l}91.80 \mathrm{a} \\
(12.26)\end{array}$ & $\begin{array}{l}24.33 \mathrm{~b} \\
(3.01)\end{array}$ & $\begin{array}{l}19.82 \mathrm{~b} \\
(0.62)\end{array}$ & $\begin{array}{l}51.95 a \\
(0.44)\end{array}$ \\
\hline Al & $\begin{array}{l}0.187 \\
(0.110)\end{array}$ & $\begin{array}{l}1.266 \\
(0.455)\end{array}$ & $\begin{array}{l}1.063 \\
(0.166)\end{array}$ & $\begin{array}{l}0.047 b \\
(0.015)\end{array}$ & $\begin{array}{l}0.342 \mathrm{ab} \\
(0.105)\end{array}$ & $\begin{array}{l}0.802 \mathrm{a} \\
(0.180)\end{array}$ & $\begin{array}{l}0.028 \mathrm{~b} \\
(0.015)\end{array}$ & $\begin{array}{l}0.220 \mathrm{~b} \\
(0.056)\end{array}$ & $\begin{array}{l}0.622 \mathrm{a} \\
(0.133)\end{array}$ & $\begin{array}{l}0.013 \\
(0.004)\end{array}$ & $\begin{array}{l}0.279 \\
(0.158)\end{array}$ & $\begin{array}{l}0.159 \\
(0.011)\end{array}$ \\
\hline DOC & $\begin{array}{l}4.38 \\
(0.78)\end{array}$ & $\begin{array}{l}15.54 \\
(4.75)\end{array}$ & $\begin{array}{l}26.52 \\
(6.97)\end{array}$ & $\begin{array}{l}1.10 \\
(0.11)\end{array}$ & $\begin{array}{l}2.47 \\
(0.54)\end{array}$ & $\begin{array}{l}11.21 \\
(4.23)\end{array}$ & $\begin{array}{l}0.74 \\
(0.21)\end{array}$ & $\begin{array}{l}1.61 \\
(0.32)\end{array}$ & $\begin{array}{l}6.64 \\
(2.45)\end{array}$ & $\begin{array}{l}0.68 \mathrm{~b} \\
(0.10)\end{array}$ & $\begin{array}{l}1.47 \mathrm{a} \\
(0.17)\end{array}$ & $\begin{array}{l}1.37 \mathrm{a} \\
(0.20)\end{array}$ \\
\hline
\end{tabular}

+ Values within a soil depth are significantly different $(p<0.05)$ among sites (SAS Institute, 2002-2003).

¥ Standard errors are in parentheses.

§ For JK, soil depths were 0-10, 10-30, and 30-90 cm; for SR, soil depths were 0-20, 20-60, and 60-90 cm; and for LG, soil depths were 0-15, 15-35, and $35-65 \mathrm{~cm}$. 


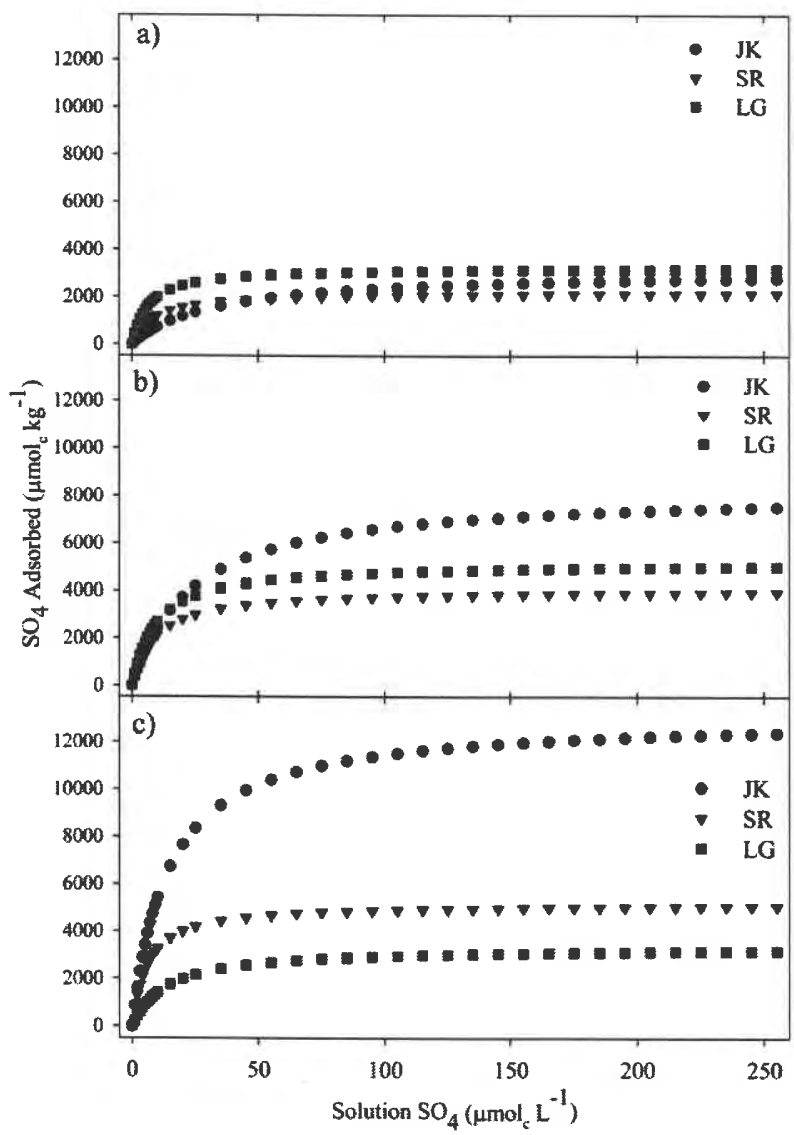

Fig. 2. Langmuir sulfur (S) isotherms for three Class I wilderness areas at the soil depth/horizons: (a) A horizon (rooting zone), (b) AB horizon, and (C) B horizon. For JK, soil depths were 0-10, 10-30 and 30-90 cm; for SR, soil depths were $0-20,20-60$, and $60-90$ $\mathrm{cm}$; and for LG, soil depths were $0-15,15-35$, and $35-65 \mathrm{~cm}$. Symbols are Joyce Kilmer/Slickrock wilderness (JK), Shining Rock wilderness (SR), and Linville Gorge wilderness (LG).

The three wilderness areas differed in their $\mathrm{S}$ adsorption capacities within the soil profile (Fig. 2). There was little variation in the maximum adsorption capacity in the surface $\mathrm{A}$ horizon soils among the three wilderness areas, ranging from $2100 \mu \mathrm{mol}_{\mathrm{c}} \mathrm{SO}_{4} \mathrm{~kg}^{-1}$ soil for SR to $3200 \mu \mathrm{mol}_{\mathrm{c}} \mathrm{SO}_{4} \mathrm{~kg}^{-1}$ soil for LG. These values suggest that A horizon soils have little capacity for additional $\mathrm{SO}_{4}$ adsorption. For $\mathrm{JK}$, current concentrations for native $\mathrm{SO}_{4}$ in A horizon soils are $64 \%$ of the maximum $\mathrm{SO}_{4}$ adsorption capacity; SR and LG are currently at 91 and $94 \%$ of the maximum. The differences among sites increased with soil depth. Joyce Kilmer/Slickrock had the greatest adsorption capacity in both the $\mathrm{AB}$ and $\mathrm{B}$ horizon soils (Fig. 2). Maximum adsorption capacity was 8200 and $13,000 \mu \mathrm{mol}_{c}$ $\mathrm{SO}_{4} \mathrm{~kg}^{-1}$ soil for the $\mathrm{AB}$ and $\mathrm{B}$ horizon, respectively. There was little difference between $S R$ and $L G$ in the $A B$ or $B$ horizon soils. For example, the maximum adsorption capacities for $\mathrm{LG}$ ranged from $3300 \mu \mathrm{mol}_{\mathrm{c}} \mathrm{SO}_{4} \mathrm{~kg}^{-1}$ soil for the $\mathrm{AB}$ horizon to $5200 \mu \mathrm{mol}_{c} \mathrm{SO}_{4} \mathrm{~kg}^{-1}$ soil for the B horizon (Fig. 2). Native $\mathrm{SO}_{4}$ concentrations in the $\mathrm{AB}$ and $\mathrm{B}$ horizon for $\mathrm{SR}$ and $\mathrm{LG}$ were close to these maximum values, averaging $87 \%$ in $S R$ and just
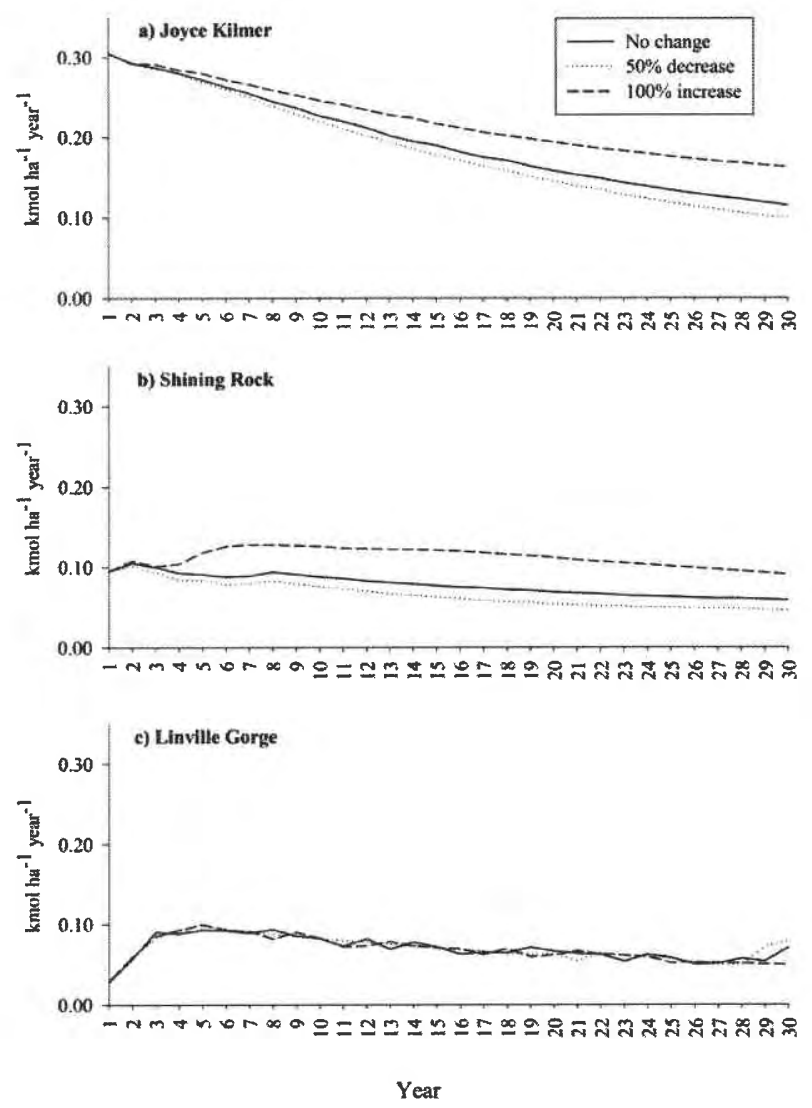

Fig. 3. Simulated calcium (Ca) leaching for three Class I wilderness areas in western North Carolina, United States: (a) Joyce Kilmer/ Slickrock wilderness; (b) Shining Rock wilderness; and (c) Linville Gorge wilderness.

over $100 \%$ in LG. This suggests that both SR and LG are close to $\mathrm{SO}_{4}$ equilibrium under current conditions.

The three wilderness areas also differed in soil acidity and chemical characteristics, factors that could influence their susceptibility to altered atmospheric deposition. Shining Rock and LG had significantly lower soil $\mathrm{pH}$, concentrations of $\mathrm{Ca}, \mathrm{Mg}$, and $\mathrm{K}$, and ECEC than JK (Table 3). The SR and LG sites were surprisingly low in soil exchangeable $\mathrm{Ca},<1.0 \mathrm{cmol}_{\mathrm{c}} \mathrm{kg}^{-1}$ (Table 3). Model predictions suggest there is more $\mathrm{Ca}$ stored in the aboveground vegetation and forest floor than in the soil. Soil exchangeable $\mathrm{Ca}$ at JK was about $50 \%$ lower than in a nearby mixed-deciduous forest in the Coweeta Basin (Johnson et al., 1993). For SR and LG, soil exchangeable Ca was $80 \%$ less than the $\mathrm{Ca}$ found in $\mathrm{A}$ horizon soils at JK (Table 3). Simulated Ca leaching at JK was $300 \%$ greater than SR or LG (Fig. 3). While Ca leaching rates at . Coweeta (Johnson et al., 1993) were in between the leaching rates of the three wilderness areas, JK, SR, and LG (Fig. 3). During the 30-yr simulation period, the $\mathrm{Ca}$ leaching at LG was not responsive to the $100 \%$ increase or $50 \%$ decrease $\mathrm{SO}_{4}$ deposition scenarios (Fig. 3). At JK and SR, simulated Ca leaching was higher with the $100 \%$ increase scenario, but only marginally influenced with the $50 \%$ decrease $\mathrm{SO}_{4}$ deposition (Fig. 3). Magnesium and $\mathrm{K}$ leaching followed similar trends as $\mathrm{Ca}$ leaching for the three wilderness 

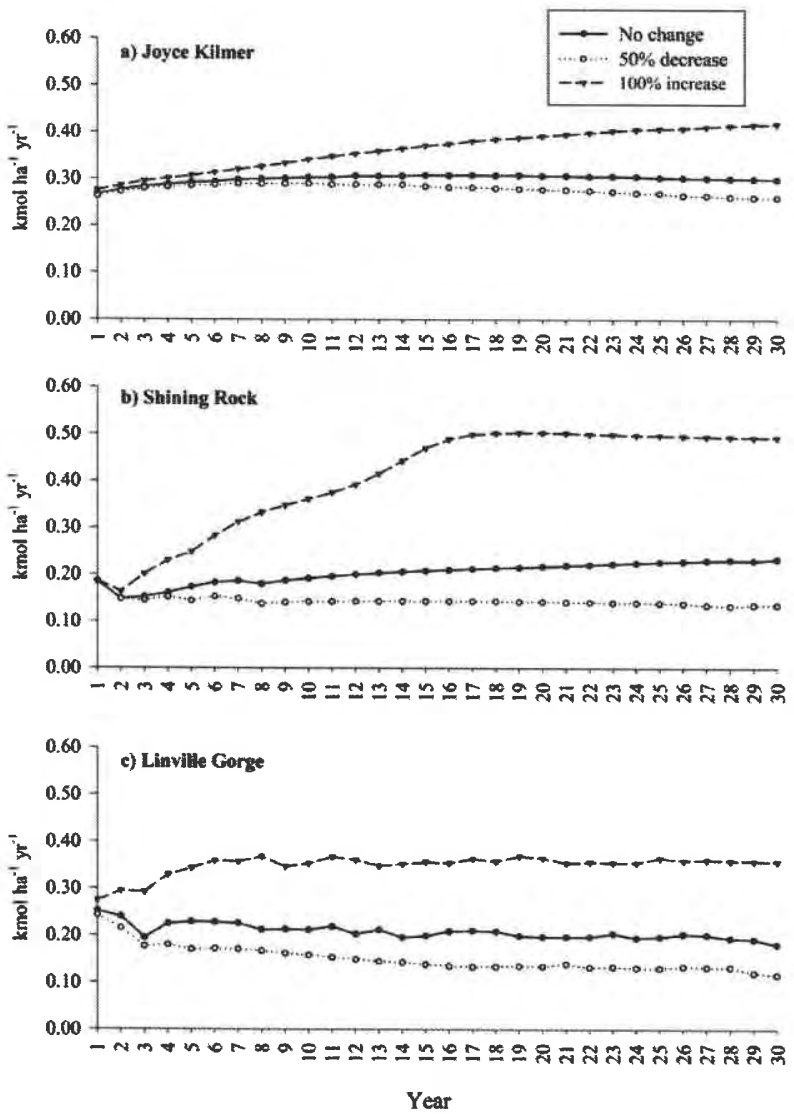

Fig. 4. Simulated sulfate $\left(\mathrm{SO}_{4}\right)$ leaching for three Class I wilderness areas in western North Carolina, United States: (a) Joyce Kilmer/ Slickrock wilderness; (b) Shining Rock wilderness; and (c) Linville Gorge wilderness.

areas (data not shown). For $\mathrm{LG}$, with higher $\mathrm{SO}_{4}$ leaching and no response in $\mathrm{Ca}$ leaching and a small increase in $\mathrm{Mg}$ and $\mathrm{Al}$ leaching ( 0.04 to $0.08 \mathrm{kmol} \mathrm{ha}^{-1} \mathrm{yr}^{-1}$ over the 30 -yr simulation) at the $100 \%$ increase $\mathrm{SO}_{4}$ deposition scenario, the additional cation that accompanied this increased $\mathrm{SO}_{4}$ was hydrogen. The $\mathrm{pH}$ was quite low and the $\mathrm{Al}$ concentration was high in the soil solution and stream water at this wilderness (Table 4).

For JK, simulated $\mathrm{SO}_{4}$ leaching decreased over the 30-yr simulation period for all $\mathrm{SO}_{4}$ deposition scenarios and was higher than the other two wilderness areas for the no change and $50 \%$ decrease scenarios (Fig. 4). Under the no change and $50 \%$ decrease scenarios, $\mathrm{SO}_{4}$ leaching for $\mathrm{SR}$ and $\mathrm{LG}$ remained relatively constant through time because they had already reached equilibrium. With the $100 \%$ increase scenario for SR and $\mathrm{LG}, \mathrm{SO}_{4}$ leaching increased through time. Simulated $\mathrm{SO}_{4}$ leaching at $S R$ and LG were much closer to those projected for a mixed deciduous forest at Coweeta (Johnson et al., 1993).

Soils do not become $\mathrm{SO}_{4}$ saturated, but reach equilibrium with respect to current inputs; thus, an increase in input concentration results in increased adsorption (Fig. 2). During the 30-yr simulation, soil adsorbed $\mathrm{SO}_{4}$ for the three wilderness areas, under the no change $\mathrm{SO}_{4}$ deposition scenario, was about $50 \mathrm{kmol} \mathrm{ha}^{-1} \mathrm{yr}^{-1}$ for $\mathrm{JK}, 20 \mathrm{kmol} \mathrm{ha}^{-1} \mathrm{yr}^{-1}$ for
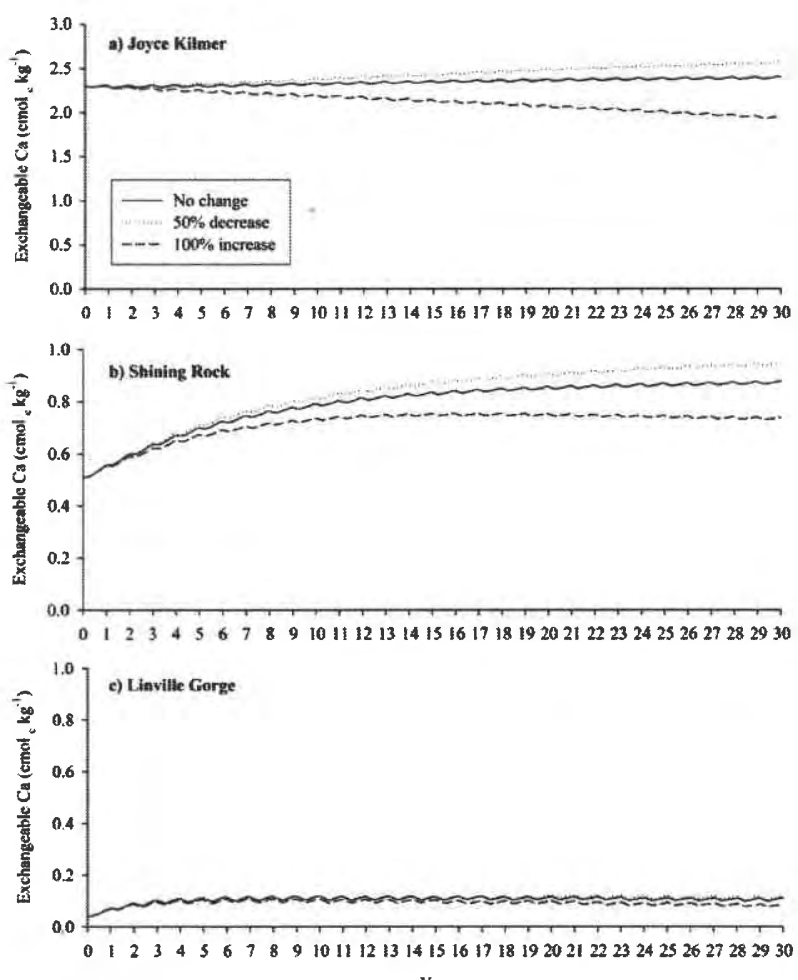

Year

Fig. 5. Rooting zone (A-horizon) soil exchangeable calcium (Ca) for three Class I wilderness areas in western North Carolina, United States: (a) Joyce Kilmer/Slickrock wilderness; (b) Shining Rock wilderness; and (c) Linville Gorge wilderness. Note difference in $y$ axis units.

$\mathrm{SR}$, and $10 \mathrm{kmol} \mathrm{ha}^{-1} \mathrm{yr}^{-1}$ for LG compared with only 2 to $4 \mathrm{kmol} \mathrm{ha}^{-1} \mathrm{yr}^{-1}$ for Coweeta (Johnson et al., 1993). The $100 \%$ increase $\mathrm{SO}_{4}$ deposition at Coweeta resulted in substantial increases in soil adsorbed $\mathrm{SO}_{4}$ to $16 \mathrm{kmol} \mathrm{ha}^{-1} \mathrm{yr}^{-1}$ by the end of the simulation (Johnson et al., 1993). In contrast, the $100 \%$ increase $\mathrm{SO}_{4}$ deposition at $\mathrm{SR}$ and $\mathrm{LG}$ resulted in an increase to 23 and $12 \mathrm{kmol} \mathrm{ha}^{-1} \mathrm{yr}^{-1}$, respectively, in less than $10 \mathrm{yr}$ (i.e., only a 2-3 $\mathrm{kmol} \mathrm{ha}^{-1} \mathrm{yr}^{-1}$ increase over the 30-yr simulation), which suggests that these two wilderness areas cannot adsorb more $\mathrm{SO}_{4}$.

Initial soil exchangeable $\mathrm{Ca}$ concentrations significantly differed among the three wilderness areas (Table 3) and exchangeable soil $\mathrm{Ca}$ did not show much response to the altered $\mathrm{SO}_{4}$ deposition scenarios (Fig. 5). Calcium replenishment at these sites is not likely because soils have developed from base-poor igneous and metamorphic parent materials; consequently, contributions from weathering are negligible (Velbel, 1992). In addition, current input from $\mathrm{Ca}$ deposition is low $\left(<0.8 \mathrm{~kg} \mathrm{ha}^{-1} \mathrm{yr}^{-1}\right)$. Even with a $50 \%$ decrease in $\mathrm{SO}_{4}$ deposition, exchangeable soil $\mathrm{Ca}$ would increase only marginally at SR and no change was obvious at LG; Ca decreased slightly in JK during the 30-yr simulation (Fig. 5). In fact, rooting zone (A horizon) base saturation was only $4 \%$ at $\mathrm{LG}$ and projected to increase by $<1 \%$ with a $50 \%$ reduction in $\mathrm{SO}_{4}$ deposition (Fig. 6). Therefore, sustainability of forest productivity at LG without $\mathrm{Ca}$ amendments is clearly in question. 

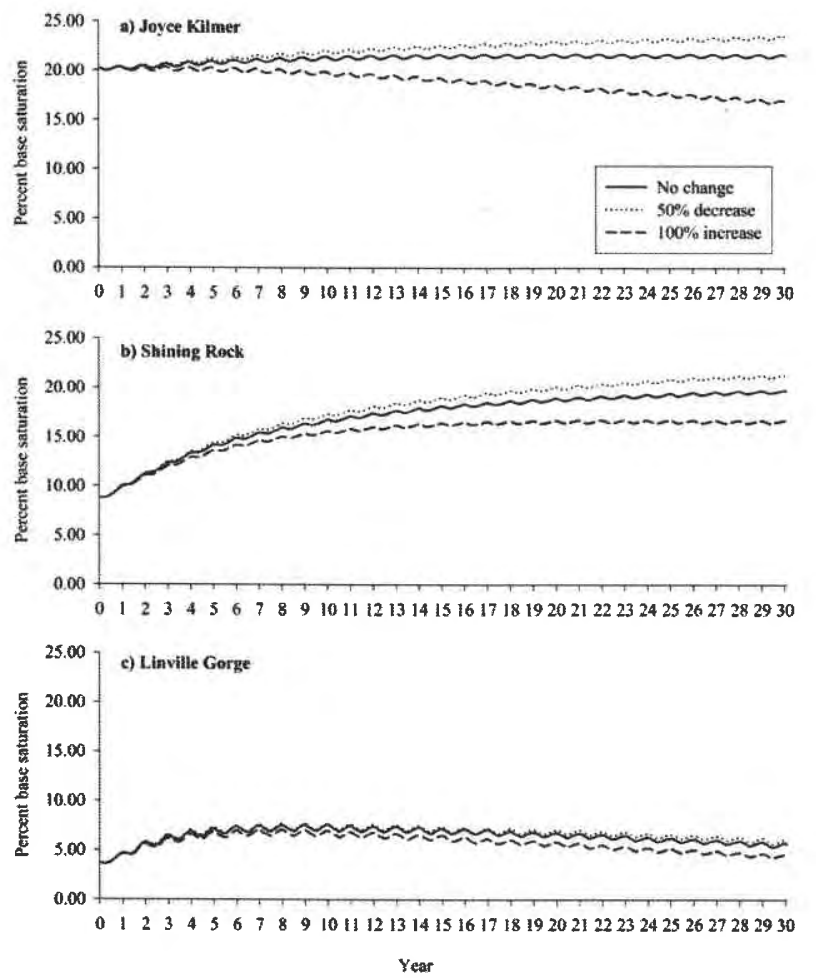

Fig. 6. Rooting zone (A-horizon) soil percent base saturation for three Class I wilderness areas in western North Carolina, United States: (a) Joyce Kilmer/Slickrock wilderness; (b) Shining Rock wilderness; and (c) Linville Gorge wilderness, western North Carolina.

Soil solution and stream chemistry were significantly different among the three wilderness areas (Table 4). In general, SR and LG had much lower soil solution $\mathrm{Ca}, \mathrm{Mg}$, and $\mathrm{K}$ and higher acid ion concentrations than JK (Table 4). In particular, $\mathrm{Ca}, \mathrm{Mg}$, and $\mathrm{K}$ were significantly lower and $\mathrm{Al}$ concentrations were significantly higher at $\mathrm{SR}$ and LG than JK. Simulations of soil solution $\mathrm{Ca}$ $\mathrm{Al}$ molar ratios were much higher at JK compared with the other two wilderness areas (Fig. 7) and continued to increase for all $\mathrm{SO}_{4}$ deposition scenarios. Simulated $\mathrm{Ca} / \mathrm{Al}$ ratios in $\mathrm{A}$ horizon solutions for SR and LG were similar to ratios found at Noland Divide, a high-elevation, spruce-fir forest in the Smoky Mountain National Park (Johnson et al., 1999). A-horizon soil solution $\mathrm{Ca} / \mathrm{Al}$ ratios at both SR and LG were $<0.3$, well below the toxicity threshold of 1 (Cronon and Grigal, 1995). These values showed some recovery, to values $>1$, after 8 yr for LG and 18 yr for SR, regardless of deposition reduction (Fig. 7). At Coweeta, soil solution $\mathrm{Al}$ concentrations $\left(<1 \mu \mathrm{mol}_{\mathrm{c}} \mathrm{L}^{-1}\right)$ were much lower than those at JK and soil solution $\mathrm{Ca} / \mathrm{Al}$ molar ratios remained at least an order of magnitude above the nominal toxicity threshold of 1 (Johnson et al., 1999). In this study, the low values of $\mathrm{Ca} / \mathrm{Al}$ ratio suggest that the forest communities at $S R$ and LG are significantly stressed under current conditions. In the southern Appalachians, high elevation spruce-fir forests tend to have thick organic horizons, high organic matter content in the mineral horizons, and low pH (Johnson et al., 1999). Because these sites have largely unreactive bedrock, base-poor litter, organic acid anions produced by the conifers, high precipitation, and high leaching rates, soil base saturation in these forests tends to be $<10 \%$ and the soil cation exchange complex is generally dominated by aluminum (Johnson and Fernandez 1992). In this study, rooting zone (A horizon) base saturation at LG was $<4 \%$; whereas, rooting zone base saturation was $8 \%$ at $\mathrm{SR}$ and $20 \%$ at JK (Fig. 5). The SR and LG sites were more similar to the high elevation spruce forest at Nolan Divide (Johnson et al., 1999) than to JK. Shining Rock and LG had low soil base saturation and soil $\mathrm{pH}$; LG also had high forest floor mass $(\mathrm{Oi}+\mathrm{Oe}+$ Oa layers) primarily due to the litter contribution from conifers (i.e., white pine and pitch pine).

Stream $\mathrm{SO}_{4}$ concentrations at $\mathrm{LG}$ were significantly higher than the other two sites, but there was no difference between JK and SR (Table 4). At LG, the $\mathrm{pH}$ of streamwater was significantly lower than the other two wilderness areas and much less than $\mathrm{pH}$ values recorded at reference watersheds streams at Coweeta (Swank and Waide 1988). At LG, stream $\mathrm{SO}_{4}$ concentration was higher than the mean values observed at Noland Divide in the Great Smoky Mountains National Park (Robinson et al., 2003), but stream $\mathrm{NO}_{3}$ concentrations were an order of magnitude lower for all three wilderness areas than that reported for Noland Divide (Robinson et al., 2003). Low $\mathrm{pH}$ and high aluminum concentrations have been shown to diminish species diversity and the abundance of invertebrates and fish in acid-impacted surface waters in the Northeast (Driscoll et al., 2003). The extremely low $\mathrm{pH}$ and high $\mathrm{Al}$ concentrations of the first-order streams at LG may place some aquatic life at risk for this wilderness. For example, in the Adirondack region of New York, lakes with $\mathrm{pH}$ between 4.0 and 4.5 supported seven species of fish, whereas lakes with $\mathrm{pH}$ ranging from 5.0 to 8.0 supported more than 100 species of fish (Driscoll et al., 2001). Low stream acid neutralizing capacity (ANC) also can adversely impact aquatic biota and fisheries, especially native brook trout (Salvelinus fontinalis Mitchill). Joyce Kilmer/Slickrock has an ANC value of $73.6 \mu \mathrm{mol}_{\mathrm{c}} \mathrm{L}^{-1}$ suggesting continued $\mathrm{S}$ deposition is unlikely to threaten brook trout populations; while the ANC value of 28.8 $\mu \mathrm{mol}_{\mathrm{c}} \mathrm{L}^{-1}$ for SR suggests extreme sensitivity to further acidification and may adversely affect brook trout. The ANC value of $-24.8 \mu \mathrm{mol}_{c} \mathrm{~L}^{-1}$ for $\mathrm{LG}$ indicates that this stream is no longer able to support brook trout or any fish species because acid inputs can no longer be neutralized (Bulger et al., 1999).

Decreases in streamwater $\mathrm{Ca}$ have been reported at several long-term monitoring studies (Swank and Waide, 1988; Likens et al., 1996; Clow and Mast, 1999; Gbondo-Tugbawa and Driscoll, 2003; Murdoch and Shanley, 2006) and have been associated with soil Ca depletion through vegetation uptake, soil leaching (Watmough et al., 2005; Duchesne and Houle, 2006), and declines in Ca deposition (Knoepp and Swank, 1994; Likens et al., 1998). In cases where there have been decreases in streamwater $\mathrm{SO}_{4}$, however, the decreases in streamwater $\mathrm{Ca}$ could be due either in part or exclusively to charge balance considerations and have little or nothing to do with changes in soils. Streamwater Ca was significantly lower at SR and LG than at JK, and streamwater Al was significantly higher at LG than at JK (Table 4). Throughout the northeastern United States, recent trends in surface water chemistry indicate that even with decreases in acidic deposition, recovery of sensitive lakes and streams is slow 
(Stoddard et al., 1999; Driscoll et al., 2001; Eimers et al., 2004). Three factors were attributed to the slow recovery: $\mathrm{Ca}, \mathrm{Mg}$, and $\mathrm{K}$ in streams were low due to declines in soil exchangeable $\mathrm{Ca}, \mathrm{Mg}$, and $\mathrm{K}$ and to a lesser extent reduction in atmospheric inputs of these ions; atmospheric $\mathrm{N}$ inputs resulted in elevated concentrations of nitrate in surface waters, contributing to acidification; and even though $\mathrm{SO}_{4}$ deposition had decreased, $S$ has accumulated in soil and is now being released to surface water as $\mathrm{SO}_{4}$. In this study, soil-extractable $\mathrm{SO}_{4}$ was significantly higher at JK and LG compared with SR (Table 3) but stream $\mathrm{SO}_{4}$ concentrations at JK were significantly lower than at LG (Table 4).

At Coweeta, $68 \%$ of the total precipitation anions were contributed by $\mathrm{SO}_{4}$ (Swank et al., 1984). In addition, high $\mathrm{SO}_{4} / \mathrm{NO}_{3}$ ratio concentrations in streamwater for the wilderness areas in this study (Table 4) indicate that most leaching of soil $\mathrm{Ca}, \mathrm{Mg}$, and $\mathrm{K}$ into drainage waters was balanced by $\mathrm{SO}_{4}$. Soil $\mathrm{SO}_{4}$ adsorption may account for some of the observed S retention (Strickland et al., 1986, Johnson et al., 1982), incorporation of inorganic $\mathrm{SO}_{4}$ into soil organic matter also plays an important role in $S$ retention (Strickland et al., 1986; Nihlgard et al., 1994). Thus, $\mathrm{SO}_{4}$ retention in soils can delay the onset of stream acidification by reducing the flux of $\mathrm{SO}_{4}$ through the soil. The $\mathrm{SO}_{4}$ adsorption isotherms and the simulation scenarios from this study suggests that $\mathrm{SO}_{4}$ retention for the SR and LG wildernesses is low, which may have contributed to more rapid soil acidification than at JK. The extremely low concentrations of exchangeable $\mathrm{Ca}, \mathrm{Mg}$, and $\mathrm{K}$ are a primary concern for all three wilderness areas, but most alarmingly at SR and LG. The soils at the latter sites are very acidic, low in weatherable minerals, and even with large reductions in $\mathrm{SO}_{4}$ and associated acid deposition, it may take decades before these systems recover from depletion of exchangeable $\mathrm{Ca}, \mathrm{Mg}$, and $\mathrm{K}$.

Shining Rock and LG are the two most sensitive wilderness areas examined in this study, soils in these two areas have experienced prolonged base cation leaching and sequestration by vegetation to such an extent that soils have been depleted of their $\mathrm{Ca}, \mathrm{Mg}$, and $\mathrm{K}$ reserves. Such depletion would greatly prolong the recovery of these watersheds under conditions of reduced $\mathrm{SO}_{4}$ deposition and may adversely impact forest productivity (Likens et al., 1998; Duchesne and Houle, 2006) and other ecosystem processes (Driscoll et al., 2003; Fenn et al., 2006; Sullivan et al., 2006).
Soil solution calcium/aluminum ratios Rooting zone (A horizon) and deeper ( $\mathrm{AB}$ and $\mathrm{B}$ horizons)
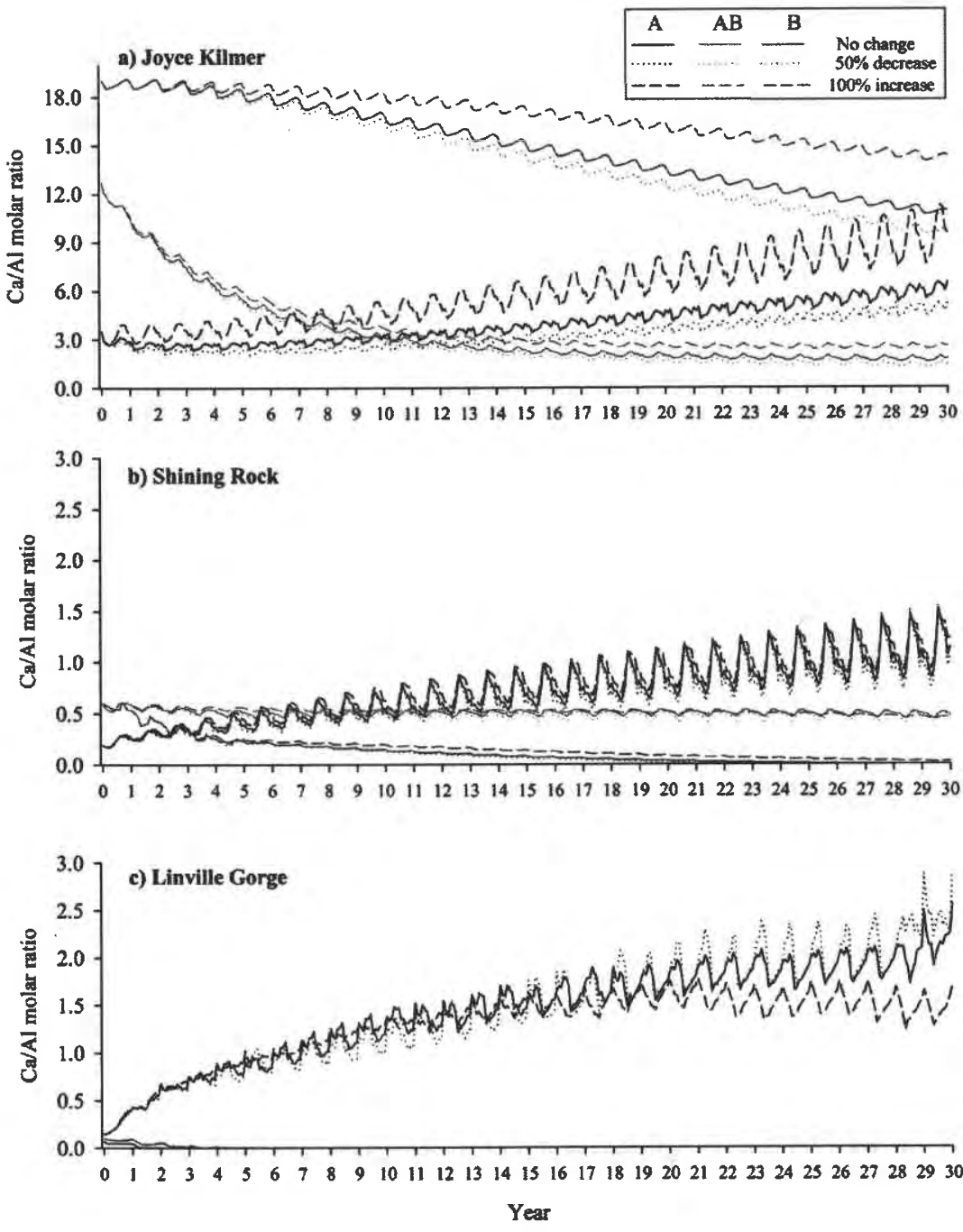

Fig. 7. Simulated soil solution molar $\mathrm{Ca} / \mathrm{Al}$ ratios for three Class I wilderness areas in western North Carolina, United States: (a) Joyce Kilmer/Slickrock wilderness; (b) Shining Rock wilderness; and (c) Linville Gorge wilderness, western North Carolina. Soil depth/horizons were $\mathrm{A}$ horizon (rooting zone), $\mathrm{AB}$ horizon, and $\mathrm{B}$ horizon. For $\mathrm{JK}$, corresponding soil depths were $0-10,10-30$, and 30-90; for SR, soil depths were 0-20, 20-60, and 60-90; and for $L G$, soil depths were $0-15,15-35$, and $35-65 \mathrm{~cm}$. Note difference in $y$ axis units.

\section{Conclusions}

Even within a relatively small geographic area in western North Carolina, Class I wilderness forest ecosystems vary considerably in their current condition and predicted susceptibility to future changes in atmospheric deposition. Due to the complexity of biogeochemical cycling processes, predicting the susceptibility to (or recovery from) changes in long-term chronic or acute deposition requires a modeling approach that is sufficiently mechanistic to represent the interactions among vegetation, soils, and hydrologic fluxes. In our model-based analyses, the SR and LG wildernesses were considerably more sensitive to increased $\mathrm{SO}_{4}$ deposition than JK. Most of this increased sensitivity was related to inherent soil factors (e.g., low $\mathrm{pH}$; low $\mathrm{Ca}, \mathrm{K}$, and $\mathrm{Mg}$ concentrations; and low 
effective $\mathrm{CEC}$ ) that reduce the soils ability to neutralize chronic and acute acidic deposition. This variation in susceptibility among wildernesses will require land managers faced with protecting wilderness and natural resource areas from anthropogenic disturbances to understand and quantify key pools and processes regulating biogeochemical cycling within sites of interest. Interestingly, model results also suggested that all three wildernesses will recover very slowly and only modestly to reductions in $\mathrm{SO}_{4}$ deposition. For example, $\mathrm{SO}_{4}$ and $\mathrm{Ca}$ leaching under the $50 \% \mathrm{SO}_{4}$ reduction scenario were only slightly less than ambient levels; even after $30 \mathrm{yr}$ of reduced $\mathrm{SO}_{4}$ inputs. For Joyce Kilmer/Slickrock, Shining Rock, and Linville Gorge, the results from this study provide information for the Federal land managers on how changes in acidic deposition might impact these three wilderness areas.

\section{Acknowledgments}

We thank Patsy Clinton, Jason Love, Bruce Bayle, and Chris Sobek for field sample collections. Cindi Brown provided development of sulfur isotherm analyses and chemical analyses. Two anonymous reviewers provided helpful comments. This work was funded by the USDA-FS and NSF Grant DEB 0218001.

\section{References}

APHA. 2000. Standard methods for the examination of water and wastewater. 20th ed. American Public Health Assoc., American Water Works Assoc., Water Environment Federation, Washington, DC.

Baier, W.G., and T.A. Cohn. 1993. Trend analysis of sulfate, nitrate and $\mathrm{pH}$ data collected at national Atmospheric Deposition Program/National Trends Network stations between 1980 and 1991. Geol. Surv. OpenFile Rep. (U.S.) 93-56 USGS, Reston, VA.

Braun, E.L. 1950. Deciduous forests of eastern North America. Blakiston, Philadelphia, PA.

Bulger, A.J., B.J. Cosby, C.A. Doloff, K.N. Eshleman, J.R. Webb, and J.N. Galoway. 1999. Shenandoah Fish and Sensitive Habitat Project Rinal Report. An Intergrated Assessment of Fish Community Responses to Stream Acidification. National Park Service, Washington, DC.

Clow, D.W., and M.A. Mast. 1999. Long term trends in streamwater and precipitation chemistry at five headwater basins in the northeastern United States. Water Resour. Res. 35:541-554.

Cronon, C.S., and D.F. Grigal. 1995. Use of calcium/aluminum ratios as indicators of stress in forest ecosystems. J. Environ. Qual. 24:209-226.

Driscoll, C.T., G.E. Likens, L.O. Hedin, J.S. Eaton, and F.H. Bormann. 1989. Changes in the chemistry of surface waters: 25-year results at the Hubbard Brook Experimental Forest, NH. Environ. Sci. Technol. 23:137-141.

Driscoll, C.T., G.B. Lawrence, A.J. Bulger, T.J. Butler, D.S. Cronan, C. Eagar, K.F. Lambert, G.E. Likens, J.L. Stoddard, and K.C. Weathers. 2001. Acidic deposition in the northeastern US: Sources and inputs, ecosystem effects, and management strategies. Bioscience 51:180-198.

Driscoll, C.T., K.M. Driscoll, M.J. Mitchell, and D.J. Raynal. 2003. Effects of acidic deposition on forest and aquatic ecosystems in New York State. Environ. Pollut. 123:327-336.

Duchesne, L., and D. Houle. 2006. Base cation cycling in a pristine watershed of the Canadian boreal forest. Biogeochemistry 78:195-216.

Eimers, M.C., P.J. Dillon, and S.A. Watmough. 2004. Long-term (18 year) changes in sulphate concentrations in two Ontario headwater lakes and their inflows in response to decreasing deposition and climate variations. Hydrol. Processes 18:2617-2630.

Fenn, M.E., T.G. Huntington, S.B. McLaughlin, C. Eagar, A. Gomez, and R.B. Cook. 2006. Status of soil acidification in North America. J. Sci. 52:3-13.

Gbondo-Tugbawa, S.S., and C.T. Driscoll. 2003. Factors controlling longterm changes in soil pools of exchangeable basic cations and stream acid neutralizing capacity in a northern hardwood forest ecosystem. Biogeochemistry 63:161-185.

Harrison, R.B., D.W. Johnson, and D.E. Todd. 1989. Sulfate adsorption and desorption in a variery of forest soils. J. Environ. Qual. 18:419-426.

Huntington, T.G., R.P. Hooper, C.E. Johnson, B.T. Aulenback, R. Capppellato, and A.E. Blum. 2000. Calcium depletion in a southeastern United States forest ecosystem. Soil Sci. Soc. Am. J. 64:1845-1858.

Jenkins, J.C., D.C. Chojnacky, L.S. Heath, and R.A. Birdsey. 2003. National-scale biomass estimators for United States tree species. For. Sci. 49:12-35.

Johnson, C.E., C.T. Driscoll, T.G. Siccama, and G.E. Likens. 2000. Element fluxes and landscape position in a northern hardwood forest watershed ecosystem. Ecosystems 3:159-184.

Johnson, D.W., and I.J. Fernandez. 1992. Soil-mediated effects of atmospheric deposition on eastern U.S. spruce-fir forests. p. 235-270. In C. Eagar and M.B. Adams (ed.) Ecology and decline of red spruce in the Eastern United States. Springer-Verlag, New York.

Johnson, D.W., G.S. Henderson, D.D. Huff, S.E. Lindberg, D.D. Richter, D.S. Shriner, D.E. Todd, and J. Turner. 1982. Cycling of organic and inorganic sulfur in a chestnut oak forest. Oecologia 54:141-148.

Johnson, D.W., J.W. Hornbeck, J.M. Kelly, W.T. Swank, and D.E. Todd, Jr. 1980 . Regional patterns of soil sulfate accumulation: Relevance to ecosystem sulfur budgets. p. 507-520. In D.S. Shriner et al. (ed.) Atmospheric sulfur deposition: Environmental impact and health effects. Ann Arbor Science Publ., Ann Arbor, MI.

Johnson, D.W., and S.E. Lindberg. 1991. Atmospheric deposition and forest nutrient cycling: A synthesis of the integrated forest study. Ecological Series 91. Springer-Verlag, New York.

Johnson, D.W., D.D. Richter, G.M. Lovett, and S.E. Lindberg. 1985. The effects of atmospheric deposition on potassium, calcium, magnesium cycling in two deciduous forests. Can. J. For. Res. 15:773-782.

Johnson, D.W., W.T. Swank, and J.M. Vose. 1993. Simulated effects of atmospheric sulfur deposition on nutrient cycling in a mixed deciduous forest. Biogeochemistry 23:169-196.

Johnson, D.W., W.T. Swank, and J.M. Vose. 1995. Effects of liming on soils and streamwaters in a deciduous forest: Comparison of field results and simulations. J. Environ. Qual. 24:1105-1117.

Johnson, D.W., P.J. Hanson, D.E. Todd, R.B. Susfalk, and C.R. Trettin. 1998. Precipitation change and soil leaching: Field results and simulations from Walker Branch Watershed, Tennessee. Water Air Soil Pollut. 105:251-262.

Johnson, D.W., R.B. Susfalk, P.F. Brewer, and W.T. Swank. 1999. Simulated effects of reduced sulfur, nitrogen, and base cation deposition on soils and solutions in southern Appalachian forests. J. Environ. Qual. 28:1336-1346.

Knoepp, J.D., and W.T. Swank. 1994. Long-term soil chemistry changes in aggrading forest ecosystems. Soil Sci. Soc. Am. J. 58:325-331.

Lawrence, G.B., M.B. David, G.M. Lovett, P.M. Murdoch, D.A. Burns, J.L. Stoddard, B.P. Baldigo, J.H. Porter, and A.W. Thompson. 1999. Soil calcium status and the response of stream chemistry to changing acidic deposition rates in the Catskill Mountains of New York. Ecol. Appl. 9:1059-1072.

Lawrence, G.B., G.M. Lovett, and Y.H. Baevsky. 2000. Atmospheric deposition and watershed nitrogen export along an elevational gradient in the Catskill Mountains, New York. Biogeochemistry 50:21-43.

Lesure, F.G., E.R. Force, and J.F. Windolph. 1977. Mineral resources of the Joyce Kilmer/Slickrock Winderness, North Carolina-Tennessee. Geol. Surv. Bull. 1416. Dep. of the Interior, USGS, Reston, VA.

Lindberg, S.E. 1992. Atmospheric deposition and canopy interactions of sulfur. p. 74-89. In D.S. Johnson and S.E. Lindberg (ed.) Atmospheric deposition and forest nutrient cycling: A synthesis of the integrated forest study. Ecological Studies 91. Springer-Verlag, New York.

Likens, G.E., C.T. Driscoll, and D.C. Buso. 1996. Long-term effects of acid rain: Responses and recovery of a forest ecosystem. Science 272:244-246.

Likens, G.E., C.T. Driscoll, D.C. Buso, T.G. Siccama, C.E. Johnson, G.M. Lovett, T.J. Fahey, W.A. Reiners, D.R. Ryan, C.W. Martin, and S.W. Bailey. 1998. The biogeochemistry of calcium at Hubbard Brook. Biogeochemistry 41:89-173.

Liu, S.A., R.K. Munsen, D.W. Johnson, S. Gherini, K. Summers, R. Hudson, K. Wilkinson, and L.F. Pitelka. 1991a. The Nutrient Cycling Model (NuCM): Overview and application. p. 583-609. In D.W. Johnson and S.E. Lindberg (ed.) Atmospheric deposition and forest nutrient cycling: A synthesis of the integrated forest study. Ecological Studies 91. Springer-Verlag, New York.

Liu, S.A., R.K. Munsen, D.W. Johnson, S. Gherini, K. Summer, R. Hudson, K. Wilkinson, and L. Pitelka. 1991b. Applications of a Nutrient Cycling Model (NuCM) to northern mixed hardwood and southern 
coniferous forest. Tree Physiol. 9:173-182.

Lorimer, C.G. 1980. Age structure and disturbance history of a Southern Appalachian virgin forest. Ecology 61:1169-1184.

Martin, J.G., B.D. Kloeppel, T.L. Schaefer, D.L. Kimbler, and S.G. McNuity 1999. Aboveground biomass and nitrogen allocation of ten deciduous southern Appalachian tree species. Can. J. For. Res. 28:1648-1659.

Mitchell, M.J., and S.E. Lindberg. 1992. Sulfur chemistry, deposition, and cycling in forests. p. 72-149. In D.W. Johnson and S.E. Lindberg (ed.) Atmospheric deposition and forest nutrient cycling: A synthesis of the integrated forest study. Ecological Studies 91. Springer-Verlag, New York.

Munsen, R.K., S. Liu, S.A. Gherini, D.W. Johnson, K.J. Wilkinson, R.J.M. Hudson, K.S. White, and K.V. Summers. 1992. NuCM Code Version 2.0: An IBM PC code for simulating nutrient cycling in forest ecosystems. Tetra-Tech, Hadley, MA.

Murdoch, P.S., and J.B. Shanley. 2006. Detection of water quality trends at high, median, and low flow in a Catskill Mountain stream, New York, through a new statistical method. Water Resour. Res. 42:8407.

National Acid Precipitation Assessment Program. 1998. Biennial Report to Congress: An Integrated Assessment. NAPAP, Silver Spring, MD.

National Atmospheric Deposition Program. 1998. National Atmospheric Deposition Program 1997 Wet Deposition. Illinois State Water Survey, Champaign, IL.

Newell, C.L., and R.K. Peet. 1995. Vegetation of Linville Gorge Wilderness, North Carolina. Curriculum in Ecology and Dep. of Biology, Univ. of North Carolina, Chapel Hill.

Newell, C.L., and R.K. Peet. 1996. Vegetation of Shining Rock Wilderness, North Carolina. Curriculum in Ecology and Dep. of Biology, Univ. of North Carolina, Chapel Hill.

Newell, C.L., R.K. Peet, and J.C. Harrod. 1997. Vegetation of Joyce KilmerSlickrock Wilderness, North Carolina. Curriculum in Ecology and Dep. of Biology, Univ. of North Carolina, Chapel Hill.

Nihlgard, B.J., W.T. Swank, and M.J. Mitchell. 1994. Biological processes and catchment studies. p. 133-161. In B. Moldan and J. Cerny (ed.) In Biogeochemistry of small catchments: A tool for environmental research. John Wiley \& Sons, New York.

National Oceanic and Atmospheric Administration. 1999. National Climatic Data Center: Daily surface data (primarily U.S.). Documentation Manual, U.S. Dep. of Commerce, NOAA, Washington, DC.

Pregitzer, K.S., and E.S. Euskirchen. 2004. Carbon cycling and storage in world forest: Biome patterns related to forest age. Glob. Change Biol. 10:2052-2077.

Reuss, J.O., and D.W. Johnson. 1986. Acid deposition and the acidification of soils and waters. Springer-Verlag, New York.

Robinson, R.B., M.S. Wood, J.L. Smoot, and S.E. Moore. 2003. Parametric modeling of water quality and sampling strategy in a high-altitude Appalachian stream. J. Hydrol. 14:24-37.

Runkle, J.R 1981. Gap regeneration in some old-growth forest of the eastern United States. Ecology 62:1041-1051.

Runkle, J.R. 1982. Patterns of disturbance in some old-growth mesic forests of eastern North America. Ecology 63:1533-1546.

SAS Institute. 2002-2003. SAS/STAT guide for personal computers. Vers.
9.1. SAS Inst., Cary, NC.

Stoddard, J.L. D.S. Jeffries, A. Lükewille, T.A. Clair, P.J. Dillion, C.T. Driscoll, M. Forsius, M. Johannessen, J.S. Kahl, J.H. Kellogg, A. Kemp, J Mannio, D.T. Monteith, P.S. Murdock, S. Patrick, A. Rebsdorf, B.L. Skjelkvåle, M.P. Stainton, T. Traaen, H. Van Dam, K.E. Webster, J. Wieting, and A. Wilander. 1999. Regional trends in aquatic recovery from acidification in North America and Europe. Nature 401:575-578.

Strickland, T.C., J.W. Fitzgerald, and W.T. Swank. 1986. In situ measurements of sulfate incorporation into forest floor and soil organic matter. Can. J. For. Res. 16:549-553.

Sullivan, T.J., I.J. Fernandez, A.T. Herlihy, C.T. Driscoll, T.C. McDonnell, N.A. Nowicki, K.U. Snyder, and J.W. Sutherland. 2006. Acid-base characteristics of soils in the Adirondack Mountains, New York. Soil Sci. Soc. Am. J. 70:141-152.

Swank, W.T., and D.A. Crossley, Jr. 1988. Forest hydrology and ecology at Coweeta. Ecological Studies 66. Springer-Verlag, New York.

Swank, W.T., J.W. Fitzgerald, and J.T. Ash. 1984. Microbial transformation of sulfate in forest soils. Science 223:182-184.

Swank, W.T., J.W. Fitzgerald, and T.C. Strickland. 1985. Transformations of sulfur in forest floor and soil of a forest ecosystem. p. 137-145. In I. Johansson (ed.) Hydrological and hydrogeochemical mechanisms and model approaches to the acidification of ecological systems. Uppsala Rep. 10. International Hydrological Programme Workshop, Norden, Sweden.

Swank, W.T., and J.B. Waide. 1988. Characterization of baseline precipitation and stream chemistry and nutrient budgets for control watersheds. p. 57-79. In W.T. Swank and D.A. Crossley, Jr. (ed.) Forest hydrology and ecology at Coweeta. Ecological Studies 66. Springer-Verlag, New York.

USDA-NRCS. 1996. Soil survey of Graham County, North Carolina. USDA-NRCS, Washington, DC.

USEPA. 1983a. Methods for chemical analysis of water and waste. Determination of nitrogen as ammonia. Method 350.1. Environmental Monitoring and Support Lab., Office of Research and Development, USEPA, Cincinnati, $\mathrm{OH}$

USEPA. 1983b. Methods for chemical analysis of water and waste. Determination of nitrite/nitrate by automated cadmium reduction. Method 353.2. Environmental Monitoring and Support Lab, Office of Research and Development, USEPA, Cincinanati, $\mathrm{OH}$.

Vanderzanden, D., H. Lachowski, B. Jackson, and B. Clerke. 1999. Mapping vegetation in the southern Appalachians with multidate satellite imagery: A wilderness case study. RSAC-2300-IRS-0009-RPT1. USDA-FS, Washington, DC.

Velbel, M.A. 1992. Geochemical mass balances and weathering rates in forested watersheds of the Southern Blue Ridge: III. Cation budget and the weathering rate of amphibole. Am. J. Sci. 292:58-78.

Vose, J.M., and W.T. Swank. 1991. A soil temperature model for closed canopied forest stands. Res. Pap. SE-281. Southeastern Forest Exp. Stn., Asheville, NC.

Watmough, S.A., J. Aherne, C. Alewell, P. Arp, S. Bailey, T. Clair, P. Dillon, L. Duchesne, C. Eimers, I. Fernandez, N. Foster, T. Larssen, E. Miller, M. Mitchell, and S. Page. 2005. Sulphate, nitrogen and base cation budgets at 21 forested catchments in Canada, the United States, and Europe. Environ. Monit. Assess. 109:1-36. 
